\title{
A Review of the Advantages and Limitations of Geophysical Investigations in Landslide Studies
}

\author{
Veronica Pazzi (D), Stefano Morelli $(\mathbb{D}$, and Riccardo Fanti \\ Department of Earth Sciences, University of Firenze, Via G. La Pira 4, 50121 Firenze, Italy \\ Correspondence should be addressed to Veronica Pazzi; veronica.pazzi@unifi.it
}

Received 30 November 2018; Accepted 27 June 2019; Published 14 July 2019

Academic Editor: Pantelis Soupios

Copyright (C) 2019 Veronica Pazzi et al. This is an open access article distributed under the Creative Commons Attribution License, which permits unrestricted use, distribution, and reproduction in any medium, provided the original work is properly cited.

\begin{abstract}
Landslide deformations involve approximately all geological materials (natural rocks, soil, artificial fill, or combinations of these materials) and can occur and develop in a large variety of volumes and shapes. The characterization of the material inhomogeneities and their properties, the study of the deformation processes, and the delimitation of boundaries and potential slip surfaces are not simple goals. Since the '70s, the international community (mainly geophysicists and lower geologists and geological engineers) has begun to employ, together with other techniques, geophysical methods to characterize and monitor landslides. Both the associated advantages and limitations have been highlighted over the years, and some drawbacks are still open. This review is focused on works of the last twelve years (2007-2018), and the main goal is to analyse the geophysical community efforts toward overcoming the geophysical technique limitations highlighted in the 2007 geophysics and landslide review. To achieve this aim, contrary to previous reviews that analysed the advantages and limitations of each technique using a "technique approach," the analysis was carried out using a "material landslide approach" on the basis of the more recent landslides classification.
\end{abstract}

\section{Introduction}

Large landslides and smaller-scale mass movements are natural widespread processes that result in the downward and outward movement of slope-forming materials, significantly sculpting the landscape and redistributing sediment and debris to gentler terrain. The rapid population growth and the pressure from human activities have strongly influenced their extension and occurrence so that they have become disasters causing vast direct and indirect socioeconomic consequences [1]. These deformations involve approximately all geological materials (natural rocks, soil, artificial fill, or combinations of these materials) and can occur and develop in a large variety of volumes and shapes [2]. Artificial fills are usually composed of excavated, transported, and placed soil or rock, but they can also contain demolition debris, ash, slag, and solid trash. The term rock refers to hard or firm bedrock that was intact and in place prior to slope movement. Soil, either residual or transported material, is used for unconsolidated particles or poorly cemented rock or aggregates. Soil is usually further distinguished on the basis of texture as debris (coarse fragments) or earth (fine fragments) according to the well-established Varnes Classification [3]. Following the recent updating of [4], more reasonable use of geotechnical material terminology (clay, silt, sand, gravel, and boulders) is starting to spread, although some classical terminologies (mud, debris, earthflow, peat, and ice) are maintained after a recalibration of their definitions, because they have acquired a recognized status in landslide science by now. The Hungr classification includes aggregations of different materials that have been mixed by geomorphic processes such as weathering, mass wasting, glacier transport, explosive volcanism, or human activity. The use of geotechnical terminology is indeed most useful, as it relates best to the mechanical behaviour of the landslide as stated by [4] and even to most common investigation methods. In any case, the distinction between different materials is usually based on interpretation of the main geomorphic characteristics within landslide deposits but can also be inferred from the geological attributes of the involved parent material. The type of material is one of the most important factors influencing the movement of landslides, which can be categorized as falls, topples, spreads, slides, or flows according to their behaviour from the source area to the final deposit through distinctive kinematics $[2,3$, 5]. Actually, the most common criterion used in landslides classification is based on the combination of the materials 
with the type of movement, but it is possible to find many other classification criteria, including velocities, volumes, water content, geotechnical parameters, and processes related to the formation of the mobilized material, among others. This is because, as stated by [5], engineering geology literature on landslides is affected by inconsistent terminology and ambiguous definitions from older classifications and current key terms for both specialists and the public. Currently, the most widely accepted and used classification is that of [2], which enhances the previous system devised by D.J. Varnes $[3,6]$. Since then, only small improvements for specific categories have occurred, such as that for flow-like landslides by [5]. In 2014 Hungr et al. [4], by maintaining the consolidated concepts introduced by [2], redefined some basic elements (basically typology and material) that still refer to the original characterization of [3] and, consequently, updated the total amount of categories (from 29 to 32), along with revisiting some of their descriptions. This new landslides classification version (Table 1), which was proposed to simplify landslides studies, is increasingly circulating in the academic world, and for this reason, it is used as the reference in the present paper.

Characterizing landslide material inhomogeneities and their properties, studying the deformation processes, and delimiting boundaries and potential slip surfaces are not simple goals. They require the availability of a wide range of data, observations, and measurements (e.g., kinematic, geomorphologic, geological, geotechnical, and petro-physical data [7]) and the evaluation of geologic and hydrologic conditions related to phenomena occurrences [8]. To obtain the needed information, many techniques including both traditional methods (detailed geomorphological surveys, geotechnical investigations, local instrumentation, and meteorological parameters analyses) and more recent methods (remotesensing satellite data, aerial techniques, and synthetic aperture radar interferometry) can be employed $[[9,10]$ and references within]. Among the latter, geophysical techniques are also included, since they are very useful in detecting the petro-physical properties of the subsoil (e.g., seismic wave velocity, electrical resistivity, dielectric permittivity, and gravitational acceleration [7]). Even though linking geophysical parameters and geological/geotechnical properties should always be supported with direct information (e.g., data from drillings), geophysical methods can provide the layered structure of the soil and certain mechanical parameters [11]. Therefore, because almost all of the advantages of geophysical methods correspond to disadvantages of geotechnical techniques and vice versa, the two investigation techniques can be considered complementary. Finally, the geophysical inversion data, and, therefore, the creation of a reliable subsoil model, is a complex and nonlinear problem that must be evaluated by taking into account all the available data on the site [11].

It is to be noted that the success of geophysical methods is mostly dependent on the presence of a significant and detectable contrast in the physical properties of different lithological units. However, in landslide characterization, geophysical contrast (i.e., differences in mechanical and physical properties) cannot be associated only with a boundary in mechanical properties (i.e., landslide boundaries) and therefore be of interest relative to the slope stability. These measured variations, in fact, could be local anomalies within the landslide or caused by the rough topography, and as a result, they could be of no or little interest [12]. This is why according to [11], the references for landslide investigation purposes are relatively few, and according to [13], there have been few landslides in which geophysical techniques were very useful. Nevertheless, the application of these techniques has changed over the years thanks to technological progress, the availability of cheaper computer electronic parts, and the development of more portable and faster equipment and new software for data processing [12], allowing the adequate investigation of 3D structures, which addresses one of the most ancient geophysical method limitations according to [11].

This review work, which starts from [11], is focused on the last twelve years of works (2007-2018) published in international journals and available online. The main goal was to analyse the geophysical community efforts in overcoming the geophysical technique limitations highlighted in the conclusion section of [11]. The drawbacks pointed out were as follows: (i) geophysicists have to make an effort in the presentation of their results; (ii) the resolution and penetration depth of each method are not systematically discussed in an understandable way; (iii) the geological interpretation of geophysical data should be more clearly and critically explained; (iv) the challenge for geophysicists is to convince geologists and engineers that $3 \mathrm{D}$ and $4 \mathrm{D}$ geophysical imaging techniques can be valuable tools for investigating and monitoring landslides; and finally, (v) efforts should also be made towards achieving quantitative information from geophysics in terms of geotechnical parameters and hydrological properties. To reach the aim, contrary to the four geophysics and landslide reviews discussed in section number $2[8,11,12,14]$ that analysed the advantages and limitations of each technique using a "technique approach," the analysis in this paper was carried out on the basis of a "material landslide approach" according to the recent landslide classification discussed above [4]. Finally, since it is beyond the aim of the work, we do not discuss the theoretical principles of the different geophysical techniques nor how to perform field surveys in this paper.

\section{Geophysical Techniques and Landslides: The State of the Art of Review Papers}

One of the first papers related to the application of geophysical techniques for the investigation of landslides, defined as a pioneering work by [11], is [8]. Herein, "landslides" are defined as a sudden or gradual rupture of rocks and their movement downslope by the force of gravity. In this paper, the main advantages of applying geophysical methods are as follows: (a) the rapid investigation of vast areas, collecting a larger number of sample points than those acquired by geologic engineering techniques; (b) the determination of the mechanical properties of wet and dry soils based on the measurements of large rock volumes directly involved in the processes; (c) the measured parameters reflect the combined geological and hydrological characteristics, which sometimes cannot be identified separately; and (d) the measurements 
TABLE 1: Nomenclature of the newly proposed landslide classification version according to [4] based on the Varnes classification system. Words divided by / (slash symbol) have to be used alternatively. In italic movement types that usually reach extremely rapid velocities as defined by [2], while for the others, the velocity varies between extremely slow to very rapid (for details, refer to [4]).

\begin{tabular}{|c|c|c|}
\hline $\begin{array}{l}\text { TYPE OF } \\
\text { MOVEMENT }\end{array}$ & ROCK & SOIL \\
\hline Fall & Rock/ice fall & Boulder/debris/silt fall \\
\hline \multirow{2}{*}{ Topple } & Rock block topple & \multirow{2}{*}{ Gravel/sand/silt topple } \\
\hline & Rock flexural topple & \\
\hline \multirow{5}{*}{ Slide } & Rock rotational slide & Clay/silt rotational slide \\
\hline & Rock planar slide & Clay/silt planar slide \\
\hline & Rock wedge slide & Gravel/sand/debris slide \\
\hline & Rock compound slide & \multirow{2}{*}{ Clay/silt compound slide } \\
\hline & Rock irregular slide & \\
\hline \multirow{2}{*}{ Spread } & \multirow{2}{*}{ Rock slope spread } & Sand/silt liquefaction spread \\
\hline & & Sensitive clay spread \\
\hline \multirow{9}{*}{ Flow } & \multirow{9}{*}{ Rock/ice avalanche } & Sand/silt/debris dry flow \\
\hline & & Sand/silt/debris flowslide \\
\hline & & Sensitive clay flowslide \\
\hline & & Debris flow \\
\hline & & Mud flow \\
\hline & & Debris flood \\
\hline & & Debris avalanche \\
\hline & & Earthflow \\
\hline & & Peat flow \\
\hline \multirow{3}{*}{ Slope Deformation } & $\begin{array}{l}\text { Mountain slope } \\
\text { deformation }\end{array}$ & Soil slope deformation \\
\hline & \multirow{2}{*}{ Rock slope deformation } & Soil creep \\
\hline & & Solifluction \\
\hline
\end{tabular}

can be repeated any number of times without disturbing the environment. Four main goals can be reached by applying vertical electric sounding (VES), seismic refraction (SR), self-potential (SP), and electromagnetic measurements (EM), listed as follows: (i) the investigation of the landslide geologic configuration, (ii) the investigation of the groundwater (determining the level and its fluctuation with time) as a landslide formation factor, (iii) the study of the physical properties and status of the landslide deposits and their changes with time, and (iv) the investigation of the landslide displacement process. Reference [8] also showed how electrical resistivity values and seismic waves velocities decrease between the bedrock and the rocks in the landslide body. Finally, in the conclusion section of [8], microseismic noise (SN) analysis is mentioned as a valuable method by which to characterize the slope soil strata.

Reference [14] conducted a review of the geophysical methods employed in landslide investigations. They highlighted that the selection of the method/s to be applied depends on its/their suitability for solving the problem. To estimate this adequacy, there are four main control factors: (i) the definition/understanding of the geophysical contrasts that have to be investigated, (ii) the evaluation of the characteristics (penetration depth and resolution) of the geophysical methods, (iii) the calibration of the acquired data by means of geological/geotechnical data, and finally, (iv) the signalto-noise ratio. In the paper, several case studies are shown wherein the SR was successfully employed to determine the lower landslide boundary.

Ten years later, the SR, seismic reflection (SRe), electrical resistivity (ER), SP, EM, and gravimetry were discussed by [12] as the most frequently used methods in landslide characterization. For each method, the author gives (i) the theoretical principles, (ii) how to perform the measurements, (iii) the sources for those which are active techniques, and, finally, (iv) some expected results. Moreover, he presents some summary tables with the physical property ranges (e.g., those of the Pwave velocity, density, and electrical resistivity) of the most common soil and rock masses in their crude form (without taking into account variations caused by different clay contents, weathering, saturation, etc.). Finally, for each discussed method, [12] synthesizes in one table its suitability for use in landslide characterization, human artefact (like pipes and foundations) identification, and physical properties determination for geotechnical purposes. Overall, the SP method results are not or only marginally suitable in all fields. Nevertheless, in the same year, [15] and, later, [16-18] showed how the SP method could be helpfully employed. From the table 
in [12], the seismic tomography and 2D and 3D geo-electric results correspond to the best methods for use in landslide characterization.

Reference [11] presents the state of the art of the geophysical techniques applied in landslide characterization based on papers after 1990. According to this review, the methods could be divided into seldom, widely, and increasingly used categories. Among the first methods they enumerate are SRe, ground penetrating radar (GPR), and gravimetry, while among the second group are SR, ER VES, or tomographies (ERT), and SP, and, finally, among the third group are SN, surface waves (SW), and EM. Moreover, they indicate seismic tomography (ST) as method useful only for limited site conditions (rock slides). They synthetize in a table (a) the main geophysical methods used, (b) the measured geophysical parameters and information type, (c) the geological context, (d) the landslide classification following [2], (e) the geomorphology, and (f) the applications (targets). According to the review in [11], there are three main advantages and three main limitations in employing geophysics for the subsurface mapping of landslides. As benefits of the geophysical methods, the author enumerates (i) the flexibility and the relative efficiency on slopes; (ii) the noninvasiveness and the generation of information on the internal structures of soil or rock masses; and (iii) the allowance of examining large volumes of soil. As drawbacks, he highlights that (i) the resolution, which is dependent on the signal-to-noise ratio, decreases with depth; (ii) the solution for a set of data is nonunique, and the results must be calibrated; and (iii) these methods yield indirect information on the subsoil, such as physical parameters rather than geological or geotechnical properties. One of the main conclusions of the review is that in landslide characterization, the geophysical survey design is still a muchdebated question, and no unique strategy has arisen from the literature.

Reference [11] is the last review published in an international journal and available online that focused on the advantages and limitations of the geophysical methods applied in landslides characterization. Reference [19], in fact, discusses, by means of case studies, benefits and drawbacks of the most common geophysical techniques (GPR, ER, and SR) in geomorphological applications. Therefore, in this paper landslides are just one of the possible fields of application. Two more recent reviews about geophysics and landslides are $[20,21]$. The first is focused only on the ERT technique applied in landslide investigations and analyses the advantages and limitations of 2D-, 3D-, and 4D-ERT (or time-lapse ERT: tl-ERT) surveys based on papers of the period from 2000 to 2013. The second is a review of the current state of the art and the future prospects of the near surface geophysical characterization of areas prone to natural hazards (e.g., landslides, rockfalls, avalanches and rock glaciers, floods, sinkholes and subsidences, earthquakes, and volcanos) published in a book series (and, therefore, not freely available online for download), wherein the analysis of the geophysical techniques applied in landslides characterization is limited to subsections of the case study section.

\section{Geophysical Techniques and Landslides: A "Landslide Approach" Analysis}

As mentioned in Introduction, this review work is based on a "material landslide approach" analysis on the basis of the more recent landslide classification presented by [4] and discussed in Introduction. Even though this classification is not widely employed (only $20 \%$ of the analysed papers from the years 2015-2018 adopted it, and these papers are marked with \# in Tables 2 and 3), we decided to use it considering that the same landslide could assume different names from paper to paper, though the authors could be more or less the same. Among the analysed papers, examples are the Super Sauze landslide and the La Vallette landslides (marked in Table 2 with $\left({ }^{\circ}\right)$ and $\left({ }^{\circ}\right)$, respectively) or the Randa landslide (marked with $\left(^{\circ}\right)$ in Table 3). This means that the analysed works are clustered and discussed in two groups, "soil" and "rock," respectively, on the basis of the material landslide type (columns 2 and 3 of Table 1).

Moreover, we decided to analyse the works starting from 2007 because the review in [20] is focused only on the ERT technique application; nevertheless, we do not analyse in detail all references already discussed therein, but we synthetize the results. The results of the review analysis are summarized in Tables 2 and 3, where for each work, we specify: (a) the landslide typology according the authors of the paper (i.e., how they refer to the landslide in the text) and (b) according to the classification from [4] (where possible, since sometimes it is not easy to identify the landslide classes from [4] on the basis of only the text); (c) the materials involved in the landslides; (d) which geophysical methods and (e) which other traditional techniques were employed; and (f)-(l) how many efforts were performed to overcome the five drawbacks highlighted by [11] and listed in Introduction. To quantify these efforts, a three-level scale was employed, where +, -, and n.d. mean, respectively, that many/some, insufficient, and nondiscussed efforts were made to overcome the limitations. Unfortunately, we know that the evaluation of how many efforts were performed could seem subjective. Therefore, in Table 4, for each drawback, we summarize how we evaluated the efforts.

3.1. "Soil" Landslides. "Soil" landslides, with respect to "rock" landslides, are the typology most studied with geophysical techniques. Among the 120 analysed papers, more than half (e.g., 66 papers, which means 75 landslides analysed without considering those reported in [20]) were about "soil" landslides, and among them, more than half were on the flow type. As summarized in Table 5, in fact, no one was focused on falls, topples, or spreads, while 28 landslides (the 37.3\%) were analysed focused on the slide (6 clay/silt rotational slides, 8 clay/silt planar slides, 11 rotational and planar slides, 1 debris slide, and 2 clay/silt compound slides), 41 (the 54.6\%) on the flows (5 sensitive clay flowslides, 9 debris flows, 5 mud flows, and 22 earthflows), and 6 (the 8.1\%) on the slope deformations (soil slope deformation). Only two of the analysed landslides were marine landslides [33, 35], indicating that it is not easy to conduct geophysical surveys to characterize landslides that dive into the sea. It is also 


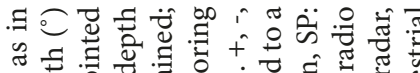

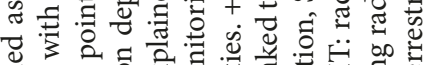

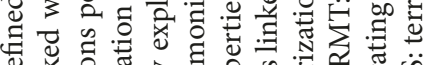

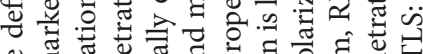

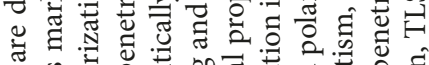

สิ

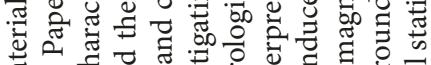

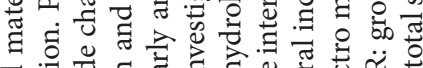

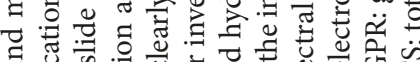

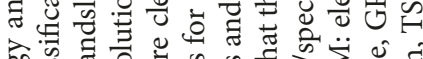

응 荝

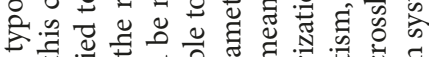

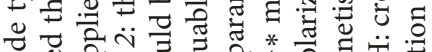

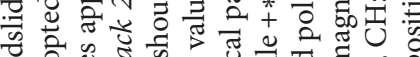

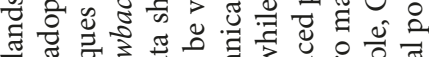

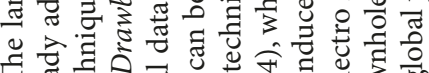

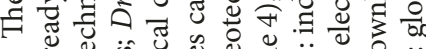

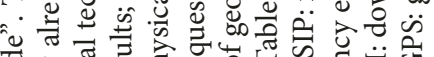

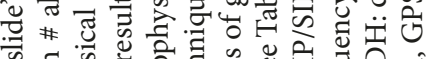

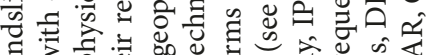

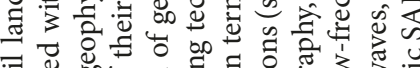

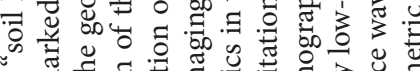

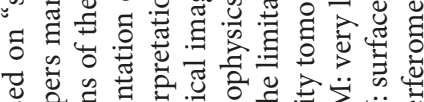

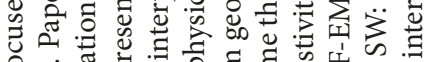

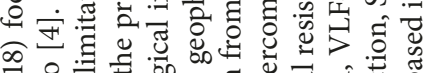

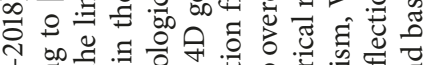

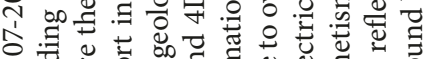

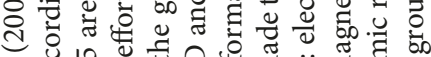

跑

Ð 。ี

记

उับ

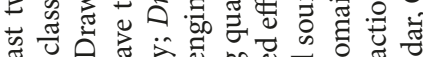

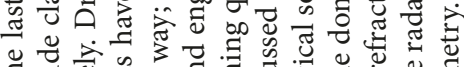

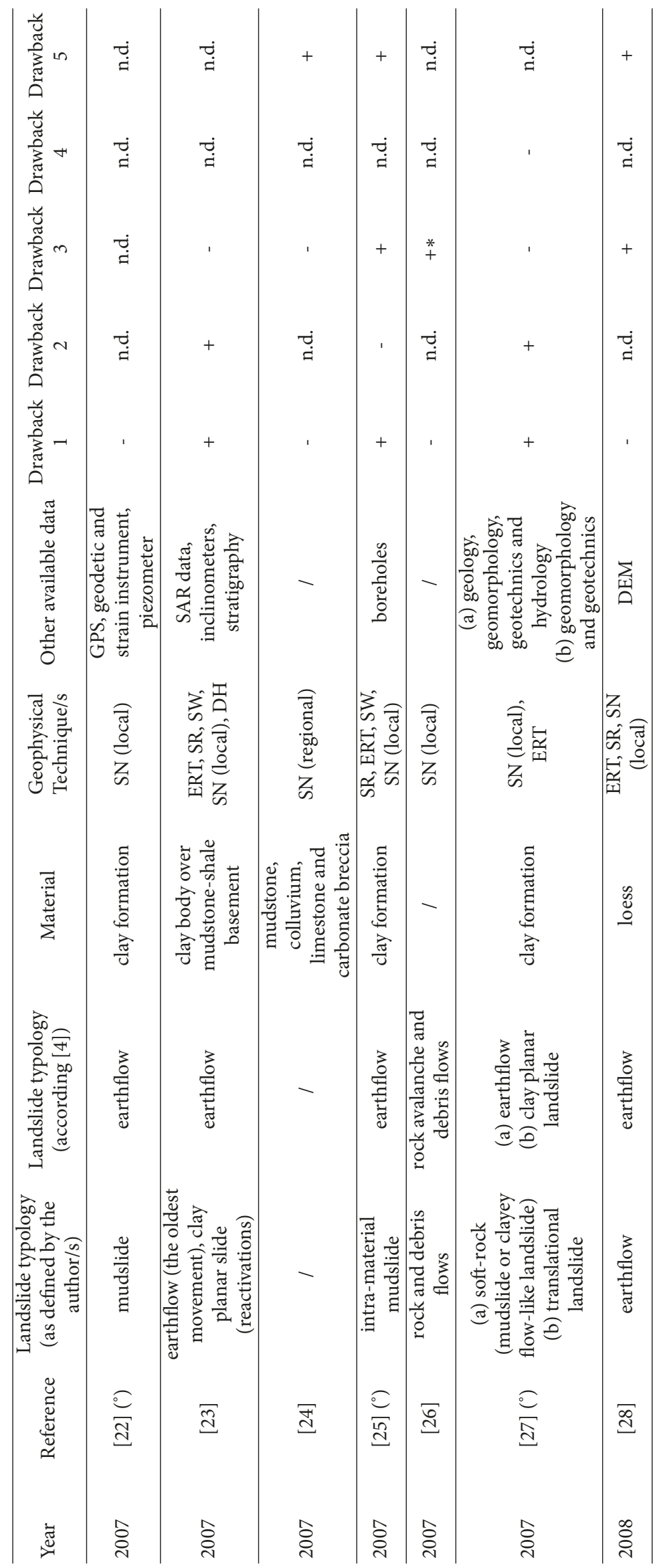
类

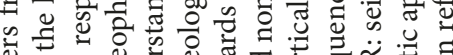

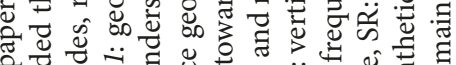

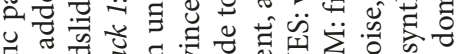

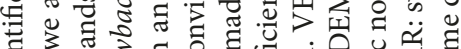

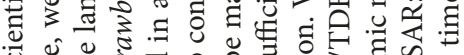

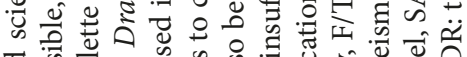
उ

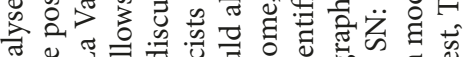

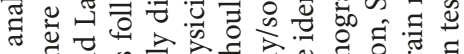

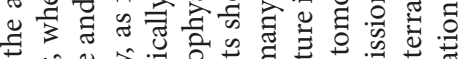

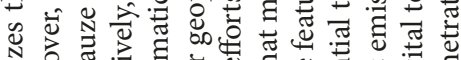

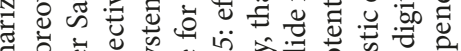

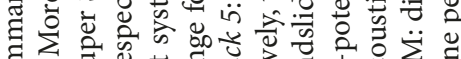

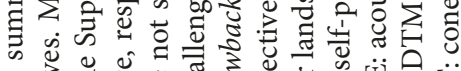
凹

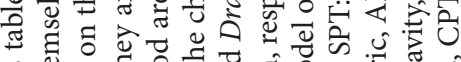

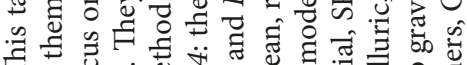

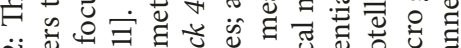
i 몀

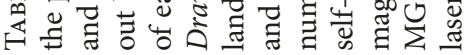




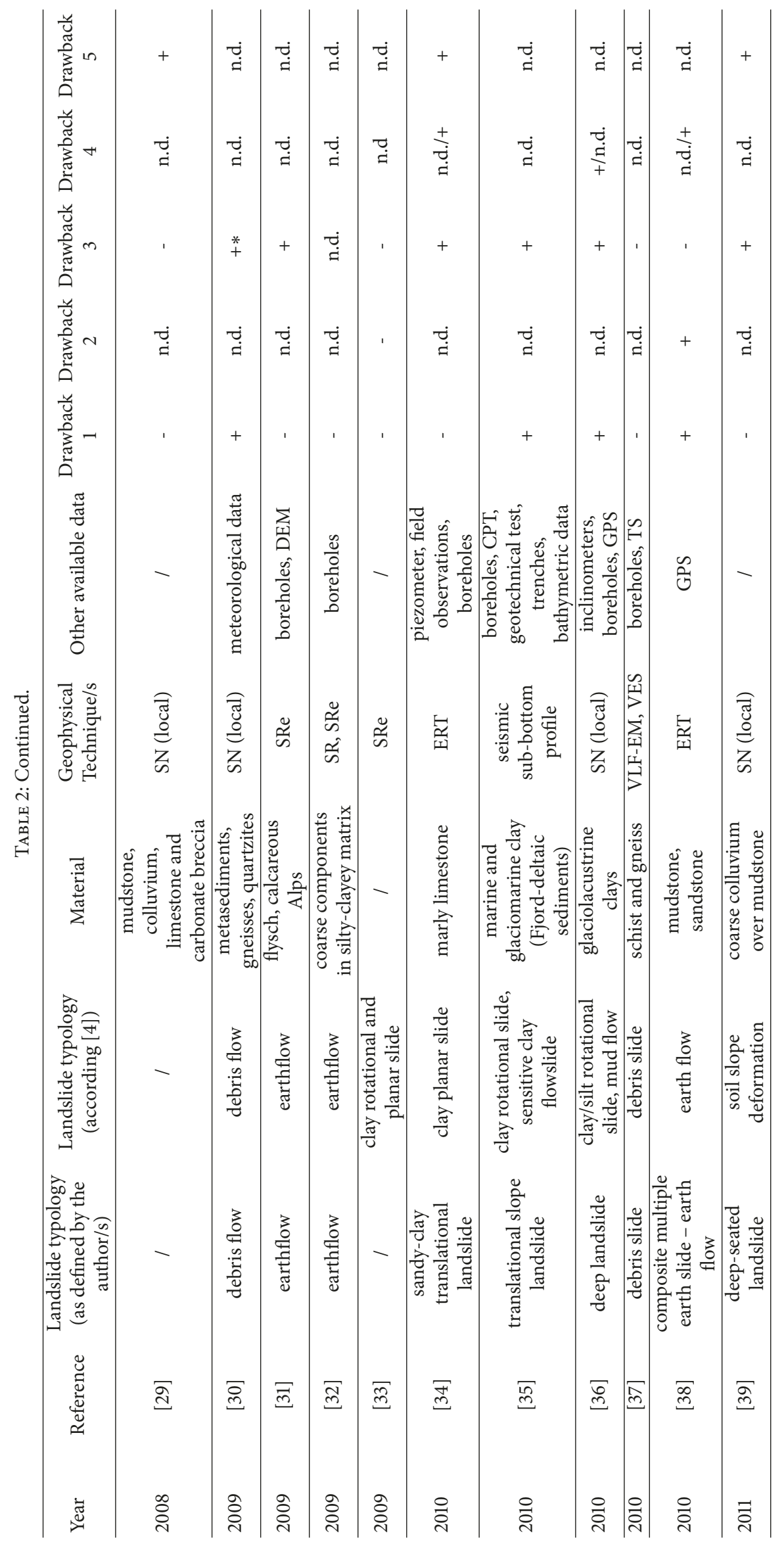




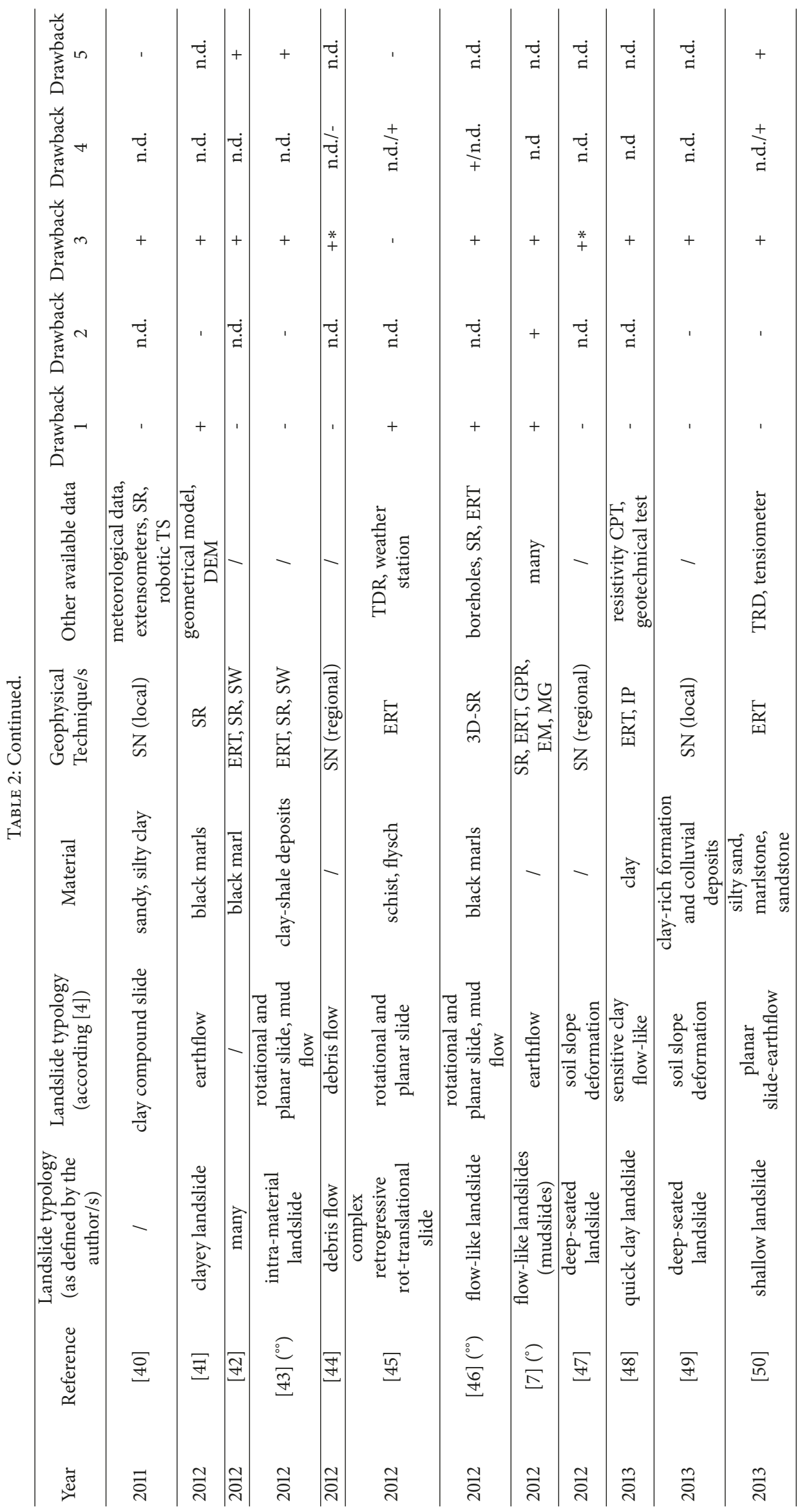


International Journal of Geophysics

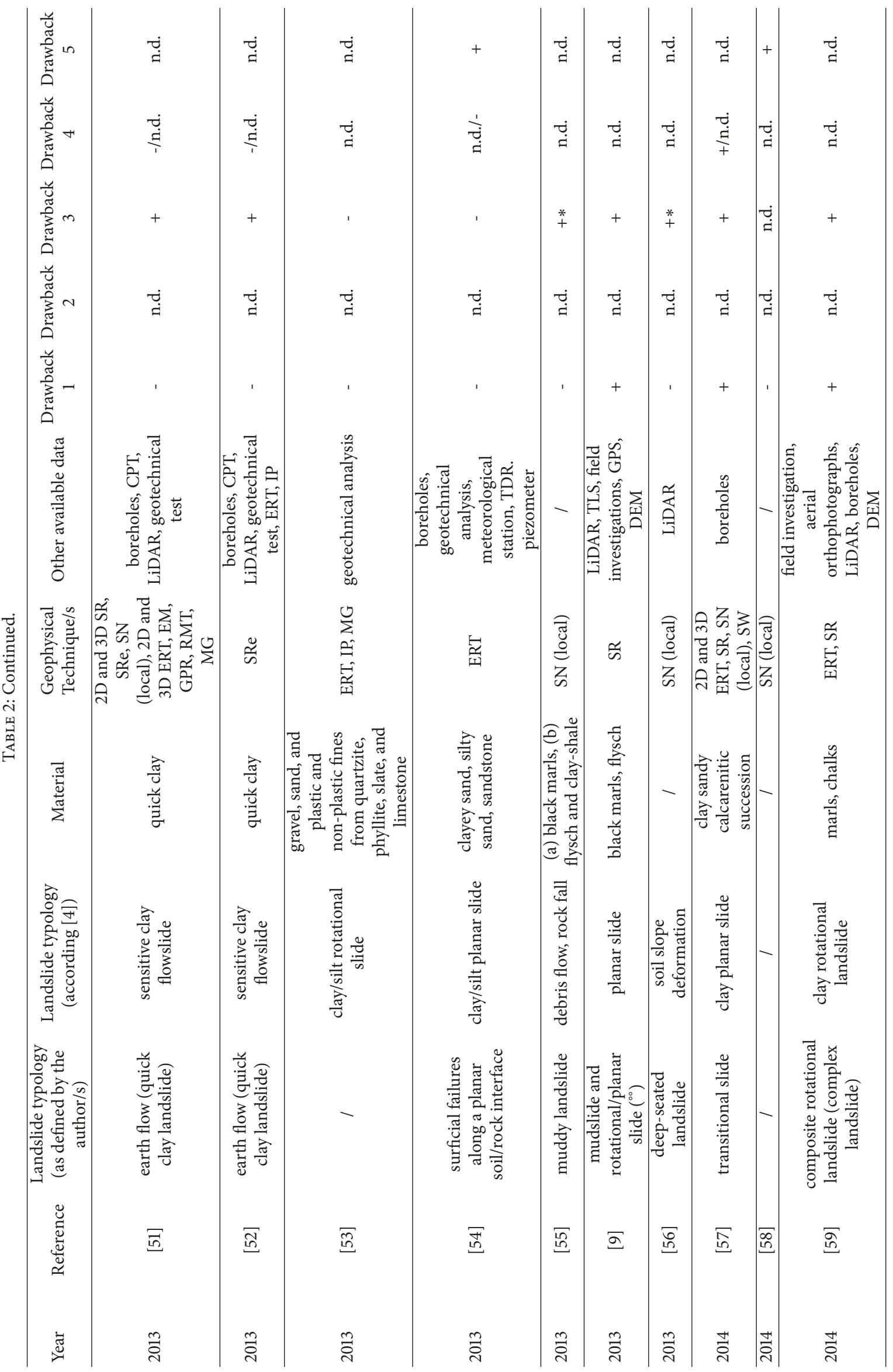




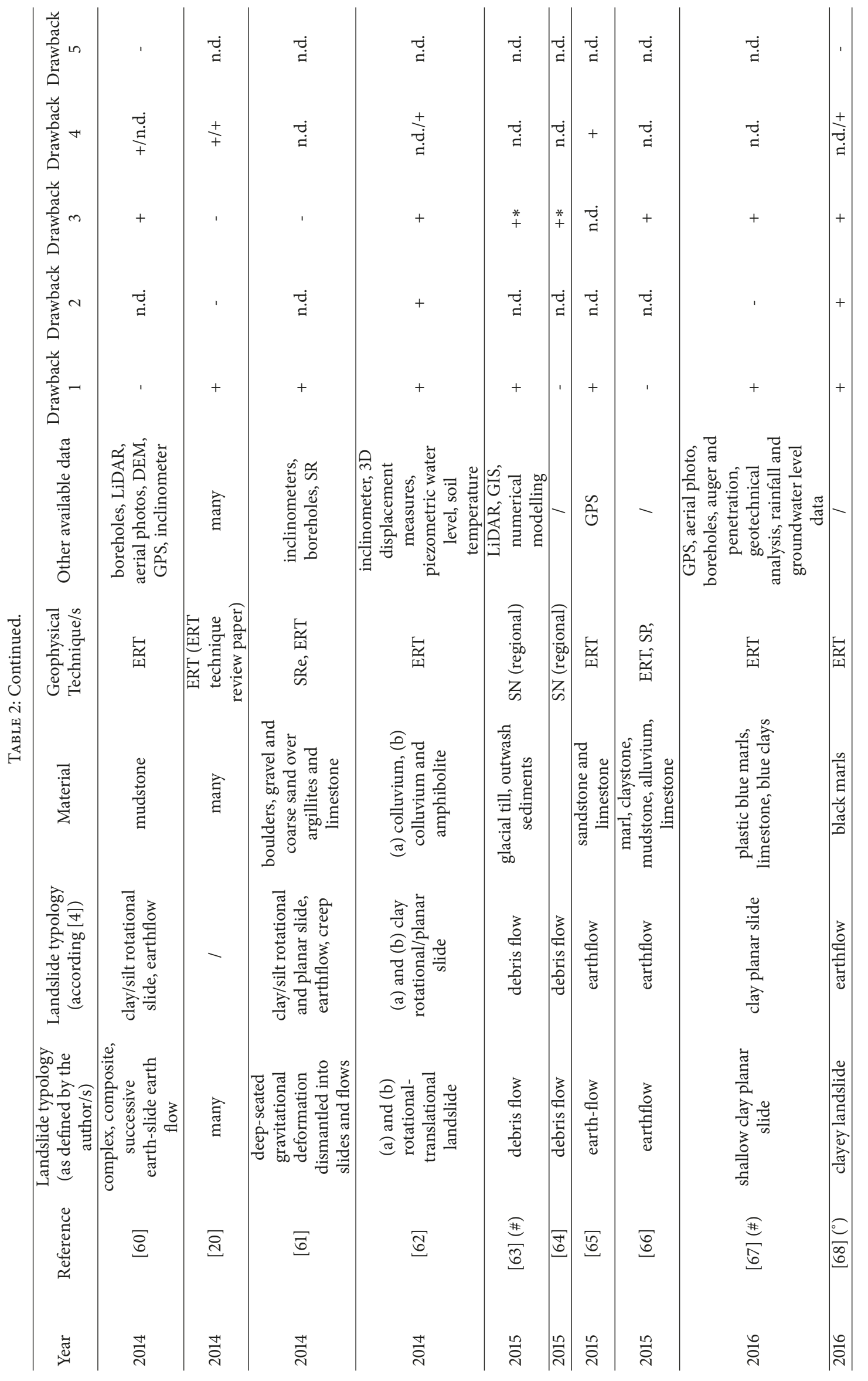




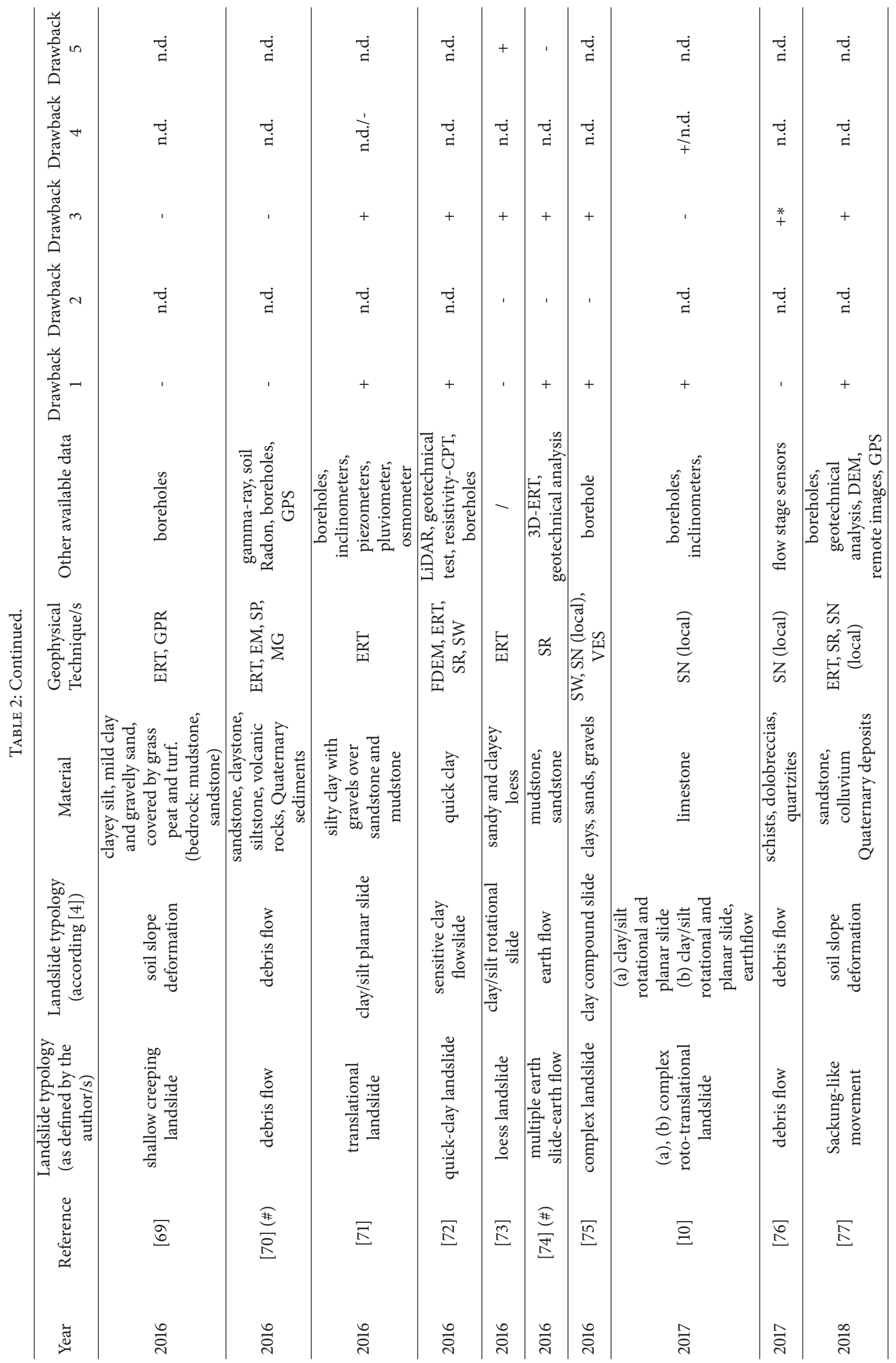




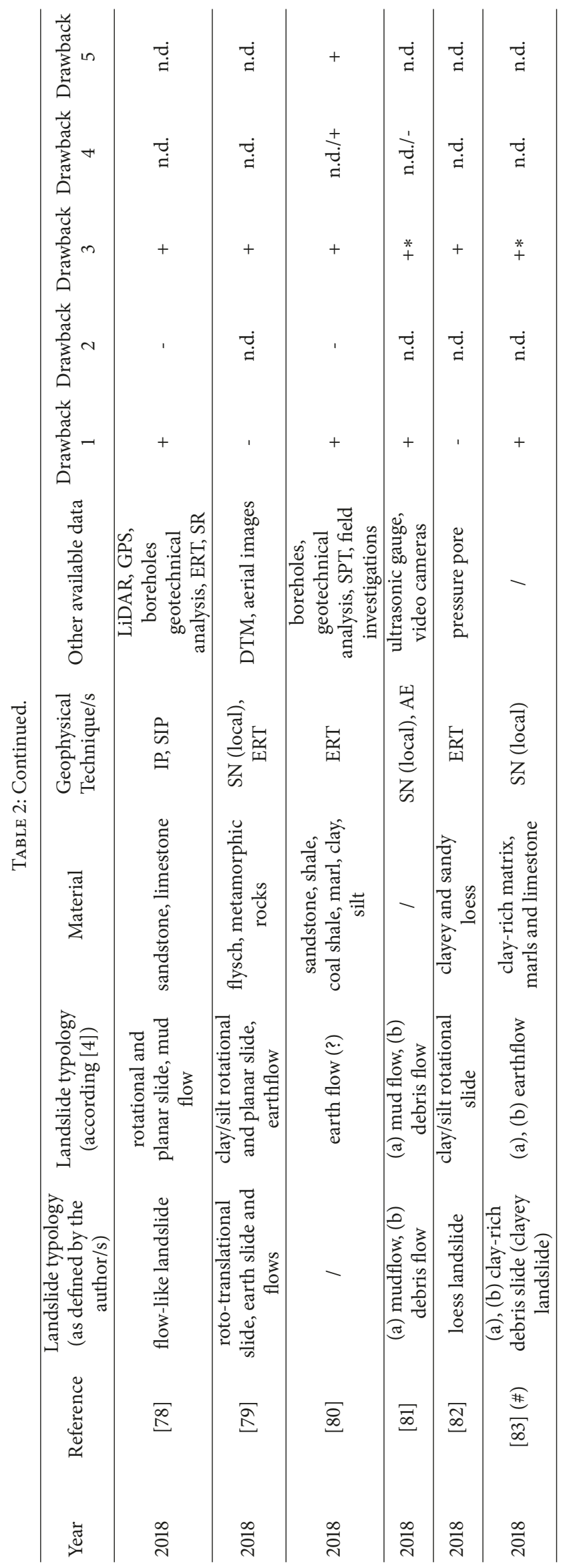




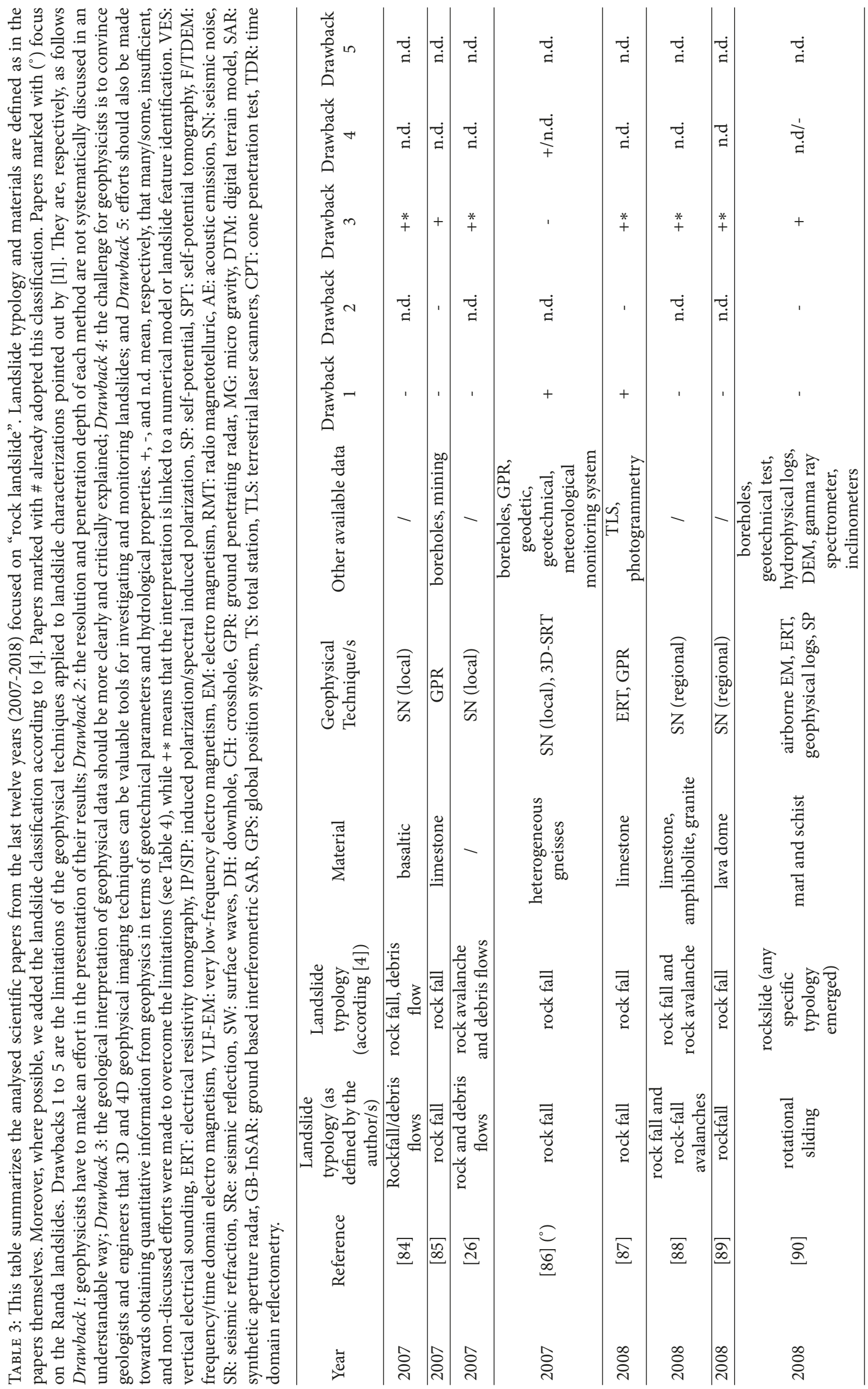




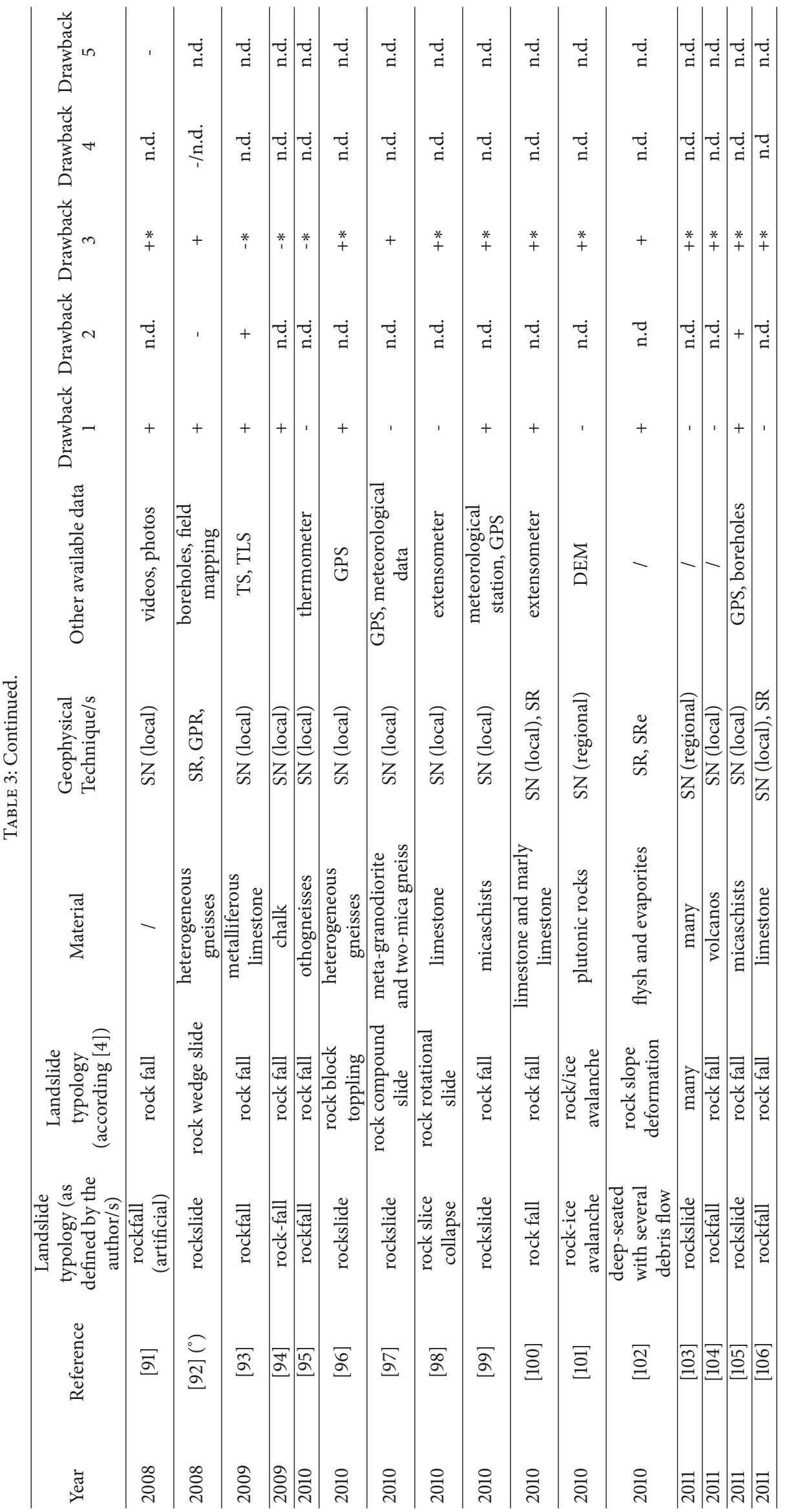




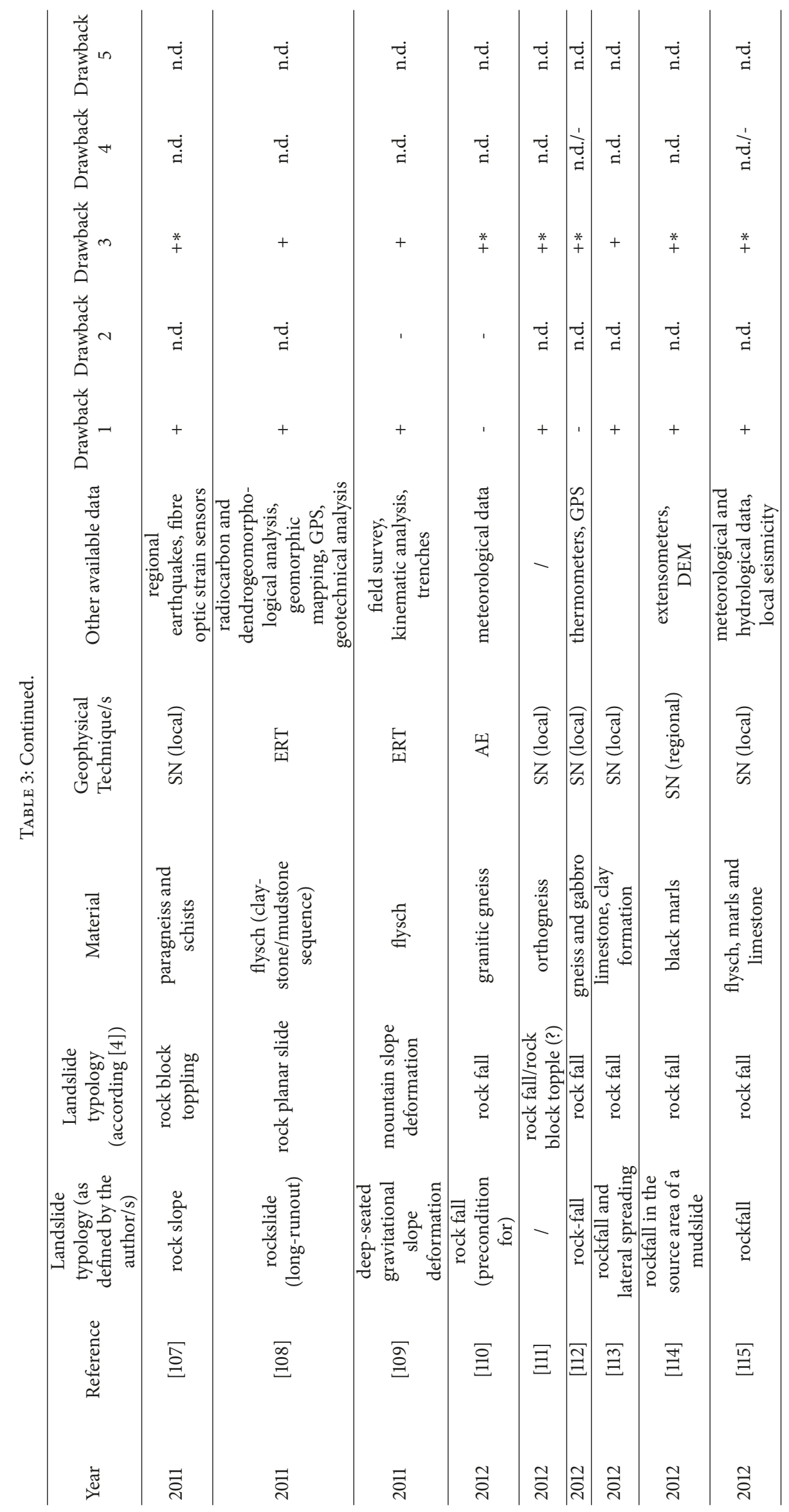




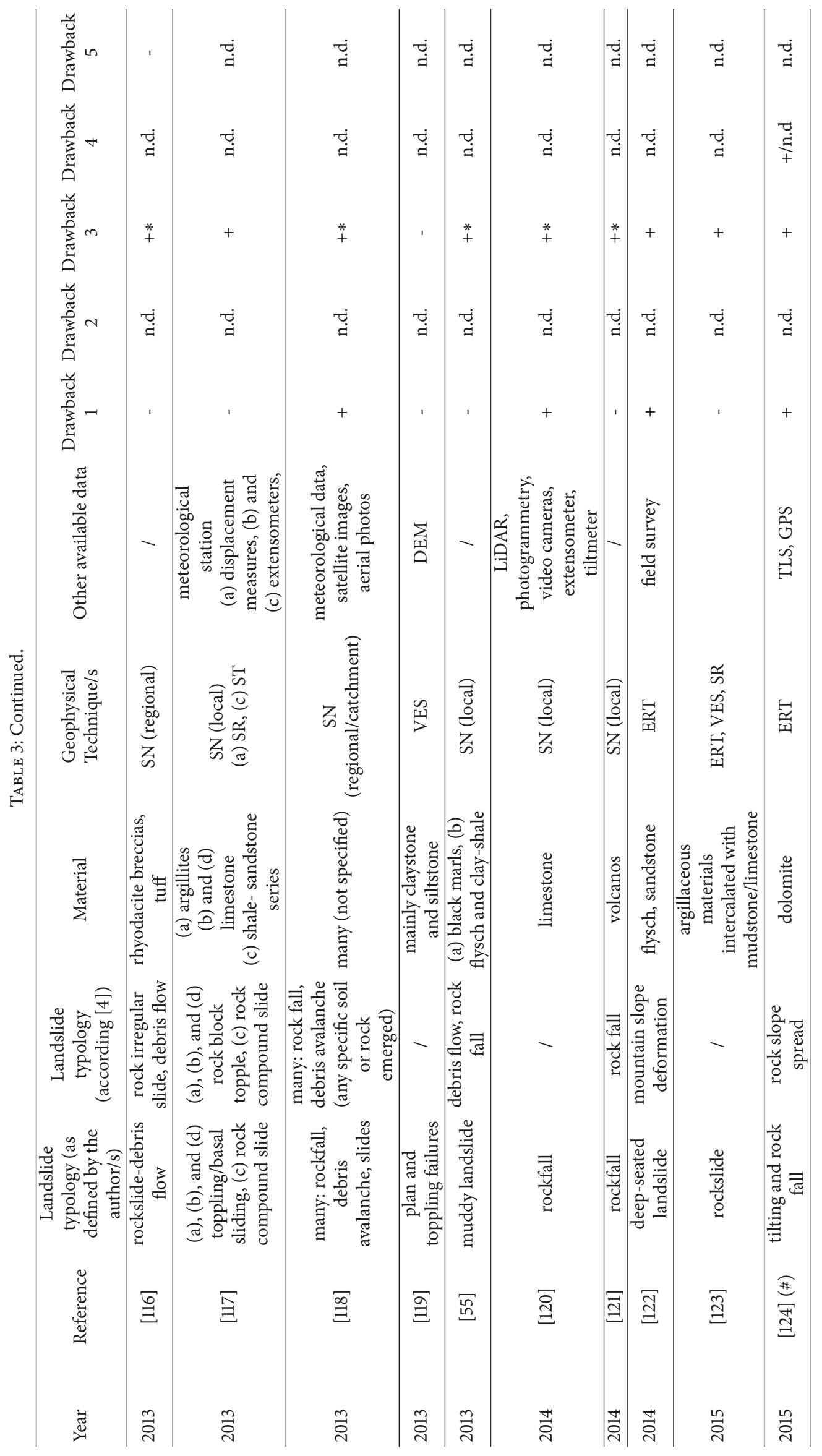




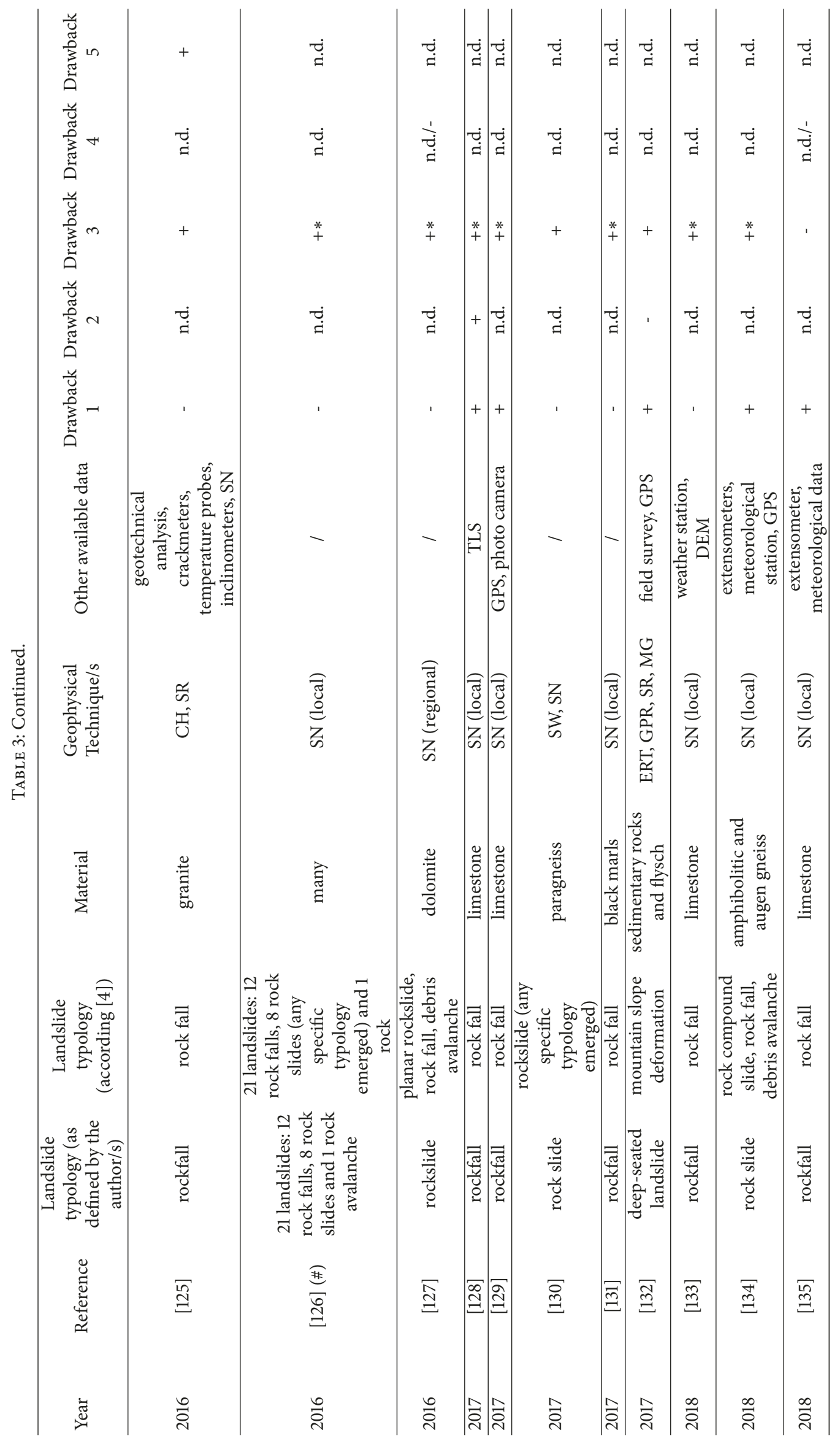


TABLE 4: For each drawback, this table explains how the three-level scale (+, -, and n.d., which mean that many/some, insufficient, and non-discussed efforts were made to overcome the limitations) was applied.

\begin{tabular}{|c|c|c|c|}
\hline & + & - & n.d. \\
\hline Drawback 1 & $\begin{array}{l}\text { (i) Coloured figures } \\
\text { (ii) 3D figures } \\
\text { (iii) Figures with } \\
\text { interpretations }\end{array}$ & $\begin{array}{c}\text { (i) B\&W figures } \\
\text { (ii) Non-interpreted } \\
\text { figures } \\
\text { (iii) Figures too small } \\
\text { (iv) Only raw data }\end{array}$ & l \\
\hline Drawback 2 & $\begin{array}{l}\text { There is wide discussion } \\
\text { about the technique/s } \\
\text { penetration depth and/or } \\
\text { resolution }\end{array}$ & $\begin{array}{l}\text { There are only some } \\
\text { mentions of the technique/s } \\
\text { penetration depth and/or } \\
\text { resolution }\end{array}$ & $\begin{array}{l}\text { There are no mentions of } \\
\text { the technique/s penetration } \\
\text { depth and/or resolution }\end{array}$ \\
\hline Drawback 3 & $\begin{array}{l}\text { There is wide discussion } \\
\text { about the geological } \\
\text { interpretation of the } \\
\text { geophysical data }\end{array}$ & $\begin{array}{l}\text { There are only some } \\
\text { mentions of the geological } \\
\text { interpretation of the } \\
\text { geophysical data }\end{array}$ & $\begin{array}{c}\text { There are no mentions of } \\
\text { the geological } \\
\text { interpretation of the } \\
\text { geophysical data }\end{array}$ \\
\hline Drawback 4 & $\begin{array}{l}\text { 3D/4D data are presented } \\
\text { and discussed }\end{array}$ & $\begin{array}{l}\text { 3D/4D data are presented } \\
\text { but they are not discussed } \\
\text { in depth }\end{array}$ & $\begin{array}{l}\text { No } 3 \mathrm{D} / 4 \mathrm{D} \text { data are } \\
\text { presented or discussed }\end{array}$ \\
\hline Drawback 5 & $\begin{array}{c}\text { There is wide discussion on } \\
\text { how to link geophysical } \\
\text { data with geotechnical } \\
\text { and/or hydrological } \\
\text { properties }\end{array}$ & $\begin{array}{l}\text { There are only some } \\
\text { mentions of how to link } \\
\text { geophysical data with } \\
\text { geotechnical and/or } \\
\text { hydrological properties }\end{array}$ & $\begin{array}{l}\text { There are no mentions of } \\
\text { how to link geophysical } \\
\text { data with geotechnical } \\
\text { and/or hydrological } \\
\text { properties }\end{array}$ \\
\hline
\end{tabular}

TABLE 5: For each type of movement and "soil" landslide typology, the table summarizes how many papers are focused on it. In italic movement types that usually reach extremely rapid velocities as defined by [2], while for the others, the velocity varies between extremely slow to very rapid (for details, refer to [4]).

\begin{tabular}{|c|c|c|c|c|}
\hline TYPE OF MOVEMENT & Number of papers & SOIL & & Number of papers \\
\hline Fall & 1 & Boulder/debris/silt fall & & 1 \\
\hline Topple & 1 & Gravel/sand/silt topple & \multirow{3}{*}{\multicolumn{2}{|c|}{$\begin{array}{l}6 \\
8\end{array}$}} \\
\hline \multirow{4}{*}{ Slide } & \multirow{4}{*}{28} & Clay/silt rotational slide & & \\
\hline & & Clay/silt planar slide & & \\
\hline & & Gravel/sand/debris slide & & 1 \\
\hline & & Clay/silt compound slide & & 2 \\
\hline \multirow{2}{*}{ Spread } & \multirow{2}{*}{ l } & Sand/silt liquefaction spread & & I \\
\hline & & Sensitive clay spread & & 1 \\
\hline \multirow{9}{*}{ Flow } & \multirow{9}{*}{41} & Sand/silt/debris dry flow & & l \\
\hline & & Sand/silt/debris flowslide & & l \\
\hline & & Sensitive clay flowslide & & 5 \\
\hline & & Debris flow & & 9 \\
\hline & & Mud flow & & 5 \\
\hline & & Debris flood & & l \\
\hline & & Debris avalanche & & l \\
\hline & & Earthflow & & 22 \\
\hline & & Peat flow & & l \\
\hline \multirow{3}{*}{ Slope Deformation } & \multirow{3}{*}{6} & Soil slope deformation & & 6 \\
\hline & & Soil creep & & l \\
\hline & & Solifluction & & 1 \\
\hline
\end{tabular}

important to point out that in our analysis, we do not consider papers focused on the geophysical characterization of quickclay that could evolve into a sensitive clay flowslide but only papers focused on those that already occurred $[35,51,52,72]$.

In only 8 works $(12.1 \%$ of the analysed "soil" landslide works), it is possible to find a detailed discussion of the theory applied to landslides, concerning either how to formulate the inversion problem $[41,46,52,55,68,83]$ or how to combine data from different surveys [7, 42]. All the other papers deal with the discussion of a case study.

A detailed analysis of the applied techniques is discussed in Section 4. Below, we present only the main considerations 
from some papers. ERT is an active geophysical method that can provide both $2 \mathrm{D}$ and $3 \mathrm{D}$ images of the subsoil. A wide review of this technique applied to landslides is provided in [20]. Therefore, here, we limit discussion to saying that in most papers (29 of 33 that present ERT applications, i.e., $88.0 \%$ ), 2D ERTs are shown, while only in $6.0 \%$ (2 papers of 33 ), 3D ERTs are shown, and in the remaining $6.0 \%$ (2 papers of 33), both $3 \mathrm{D}$ and $2 \mathrm{D}$ applications are presented.

Since the ' 60 s, passive seismic techniques have been developed to monitor and characterize signals triggered by landslide dynamics and related changes in the material mechanical properties (i.e., (i) material bending, shearing, or compression; (ii) fissure opening; (iii) slipping at the bedrock interface; and (iv) debris flows or mudslides) [22, 55]. They are of great interest in (a) detecting debris flows [30], (b) assessing site effects [24, 29], (c) detecting landslide slip surfaces [10], and (d) estimating the thickness of a material that could be mobilized by a landslide [136]. Another advantage of this method is its ability to detect remote events that might otherwise go unnoticed for weeks or months. The main difficulties arise from two issues: (i) the seismic signatures of landslides and mud/debris flows are very complex and cannot be effectively identified without a detailed waveform analysis and (ii) the epicentres of landslides and mud/debris flows cannot be confidently determined by conventional earthquake-locating methods, mainly due to the lack of clear arrivals of $\mathrm{P}$ and $\mathrm{S}$ phases [44].

3.2. "Rock" Landslides. Among the 120 analysed papers, less than half (e.g., 54) were about "rock" landslides, and the majority discussed were of the rock fall type. As summarized in Table 6 the landslide typology is divided as follows: 41 (the $54.6 \%$ ) falls, 5 (the 6.7\%) topples (5 block topples), 18 (the $24.0 \%$ ) slides (1 rotational, 2 planar, 1 wedge, 3 compound, 1 irregular), 1 (the 1.3\%) spread (rock slope spread), 6 (the 8.0\%) flows (avalanches), and 4 (the 5.4\%) slope deformations (3 mountain slope deformations and 1 rock slope deformation). In all the works that discuss the application of seismic techniques $[26,55,84,86,87,89,91,93-101,103-107,111-$ $118,120,121,126-128,130,131,133,134]$, it is possible to find a more- or less-detailed discussion on the theory of the seismic wave analysis carried out to find the "rock" landslide features.

"Rock" landslides are well-known phenomena but are poorly understood. Contrary to other landslide types, rockfalls are usually sudden phenomena with few apparent precursory patterns observed prior to the collapse. A key point in the prediction of rock slope failure is better knowledge of the internal structure (e.g., the persistence of joints), which requires an interdisciplinary research field among rock mechanics, rock engineering, and mining [98]. This is why in $64.8 \%$ of the analysed papers, the geophysical technique is carried out along with more traditional methods (i.e., boreholes, mining, extensometers, and inclinometers). Moreover, there are at least two limitations in applying geophysical methods for rock deposits: (a) the difficulty of deploying sensors (i.e., ER electrodes, geophones, or GPR antennas) on sharp and blocky ground with a high void ratio and (b) the low geophysical contrast between the rock deposit and the underlying layers with comparable properties [[137], not listed in Table 3 because it was already analysed by [20]]. In [137], there is another limitation in applying geophysics for rock deposits: the presence of a shallow geophysical contrast caused by the subsoil water table that could mask deeper interfaces. Nevertheless, this limitation also has to be considered for "soil" landslides.

More recently, to overcome these limitations, rock slope stability characterization and monitoring has been carried out using passive seismic techniques (see also the discussion session), implemented initially in open-mine monitoring [98]. These techniques, in fact, could help in (i) understanding the seismic responses of rock to slope deformation (e.g., the release of stored elastic energy under particular conditions) $[135,138]$, (ii) detecting and locating microearthquakes generated by fracturing within unstable rock masses (major effort is required for classifying seismic signals and extracting those related to landslides [86, 99, 129]), and (iii) identifying remote events that could otherwise go unnoticed for weeks or months. Therefore, these methods are applied to avalanches $[26,84,101,126]$, rock topplings $[107,111,117,134]$, rockslides $[55,96-99,103,116,126,127,130]$, and rock falls or cliff failures $[86,88,89,91,93-95,100,104-106,112-115,118,120,121,126$, $128,131,133]$. Finally, some works are focused on finding the relation among "rock" landslides, displacement rate measurements, and meteorological (i.e., rain and temperature) parameters $[95,99,100]$.

\section{Discussion}

Most studies focused on geophysical surveys are applied (a) to explore the subsoil for mineral deposits or fossil fuels, (b) to find underground water supplies, (c) for engineering purposes, and (d) for archaeological investigations [19]. Technological progress and the availability of cheaper computer electronic parts has allowed the improvement of more portable equipment and the development of $2 \mathrm{D}$ and $3 \mathrm{D}$ geophysical techniques $[11,12]$. Therefore, the applicability of geophysical methods in landslide characterization has grown over the years. Starting from the state of the art of the geophysical techniques applied in landslide characterizations pointed out in [12], this review focused on the papers from the last twelve (2007-2018) years and tried to understand how many efforts have been made by the international scientific community to overcome the drawbacks. These geophysical techniques limitations are listed in Introduction. To reach the goal of this paper, contrary to the four reviews discussed in Section $2[8,11,12,14]$, the analyses of the geophysical method advantages and limitation were carried out on the basis of the latest landslide classification, which is mainly based on the involved materials and geotechnical properties [4]. Therefore, the 120 analysed papers were divided into two classes: "soil" (in red in the following figures) and "rock" (in green in the following figures), which account for 66 and 54 works, respectively.

Even though it is well known that it is better to integrate more than one geophysical technique because of the intrinsic limitations of each approach, in $68.3 \%$ of the analysed papers (Figure 1), only one geophysical method is presented and discussed. However, in $64.6 \%$ of these works (which 
TABLE 6: For each movement type and "rock" landslide typology, the table summarizes how many papers are focused on it. In italic movement types that usually reach extremely rapid velocities as defined by [2], while for the others, the velocity varies between extremely slow to very rapid (for details, refer to [4]).

\begin{tabular}{lccc}
\hline TYPE OF MOVEMENT & Number of papers & ROCK & Number of papers \\
\hline Fall & 41 & Rock $/$ ice fall & 40 \\
\hline Topple & 5 & Rock flexural topple & 5 \\
& & Rock rotational slide & Rock planar slide \\
& & Rock wedge slide & 1 \\
Slide & 18 & Rock compound slide & 1 \\
& & Rock irregular slide & 3 \\
Spread & & Rock slope spread & 1 \\
\hline Flow & 1 & Rock/ice avalanche & 1 \\
Slope Deformation & 6 & Mountain slope deformation & 3 \\
\hline
\end{tabular}

correspond to $44.1 \%$ of the total analysed papers, as indicated by the bottom/darker part of the blue bar in Figure 1), the geophysical results are interpreted on the basis of other techniques. This means that only in $24.2 \%$ of the analysed works (the top/lighter part of the blue bar in Figure 1) is just one technique presented, and in $80 \%$ of these $24.2 \%$ (which means four works out of five), the employed method is a passive seismic technique. This is probably because these techniques (a) require quite light equipment, (b) can be employed to both monitor and characterize seismic signals triggered by landslide dynamics $[55,133,134]$, and (c) can be useful for overcoming the unpredictable occurrence of rockfalls [128], even though it is not easy to correlate seismic signal features with landslide geological properties $[120,134]$.

In general, active and passive seismic methods are the most employed in landslide characterization and monitoring (Figure 2). In "soil" landslides, the three most employed techniques are ERT, SN (at local and regional scales), and SR. The last, together with SRe and SW, is largely used in this kind of landslide typology, and in general, it is easier to find papers focused on "soil" landslides that integrate the abovementioned seismic techniques with other less-common techniques (e.g., MG, IP, SP, and EM). Our analysis of "soil" landslides confirms the conclusions of [20]; i.e., (a) ERT and SR integration proves to be the most effective, (b) the joint application of ERT, SR, and GPR seems to solve and overcome the resolution problems of each single method, and (c) in the literature, there are very few examples of ERT combined with IP to distinguish clayey material or to better interpret ERT. In "rock" landslides, the three most employed techniques are SN (at local and regional scales), ERT, and SR, indicating that passive seismic techniques are preferred over electrical ones. As mentioned above, this is probably because they can be employed to both monitor and characterize seismic signals triggered by landslide dynamics $[55,133,134]$. At the fourth position is GPR, although the authors highlight both the difficulty of deployment on cliffs and the limitation of its applicability to only highly resistive rock slopes $[87,88,92$, 132].

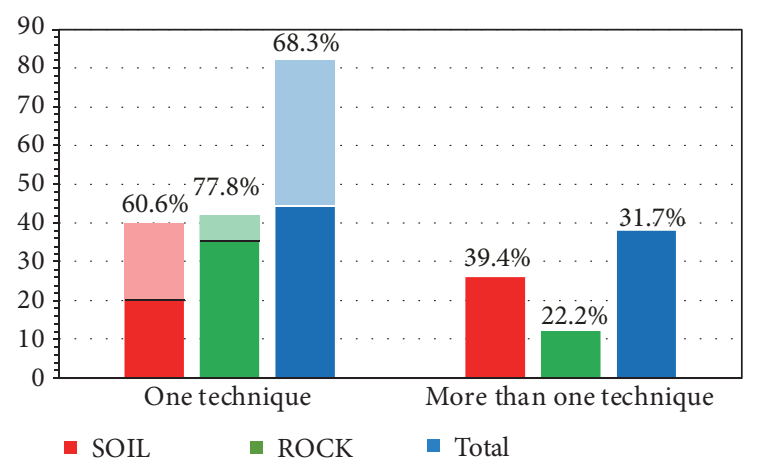

FIGURE 1: For each landslide typology ("soil" in red, "rock" in green, and total in blue), the bar graph shows the number of papers focused on just one technique or on more than one. Numbers on the top of the bars are the percentage values with respect to the total number of analysed papers. The darker colours of the "soil" and "rock" bars of the "one-technique" group indicate in how many works the passive seismic technique was employed alone. The dark blue portion of the "one-technique total bar" indicates in how many works other nongeophysical techniques were employed.

In Figure 3, for each drawback, the percentages and the numbers of papers (numbers on the top of the bars) that fall into each level of the three-level scale (+, -, and n.d., which mean that many/some, insufficient, and nondiscussed efforts were made to overcome the limitations, as shown in Table 4) are summarized. In general, it is possible to observe that great efforts were made ( 95 papers out of the 120 analysed, which is $79.1 \%$, are on the + level of the scale) to improve the geological interpretation of the geophysical data and to explain it more clearly and critically (drawback 3 ). In contrast, very few efforts were made to (a) systematically discuss, in an understandable way, the resolution and penetration depth of each method (drawback 2: 91 papers out of the 120 analysed, which are $75.8 \%$, are on the n.d. level of the scale), (b) to convince geologists and engineers that $3 \mathrm{D}$ and $4 \mathrm{D}$ geophysical imaging techniques can be valuable tools for investigating and monitoring landslides (drawback 


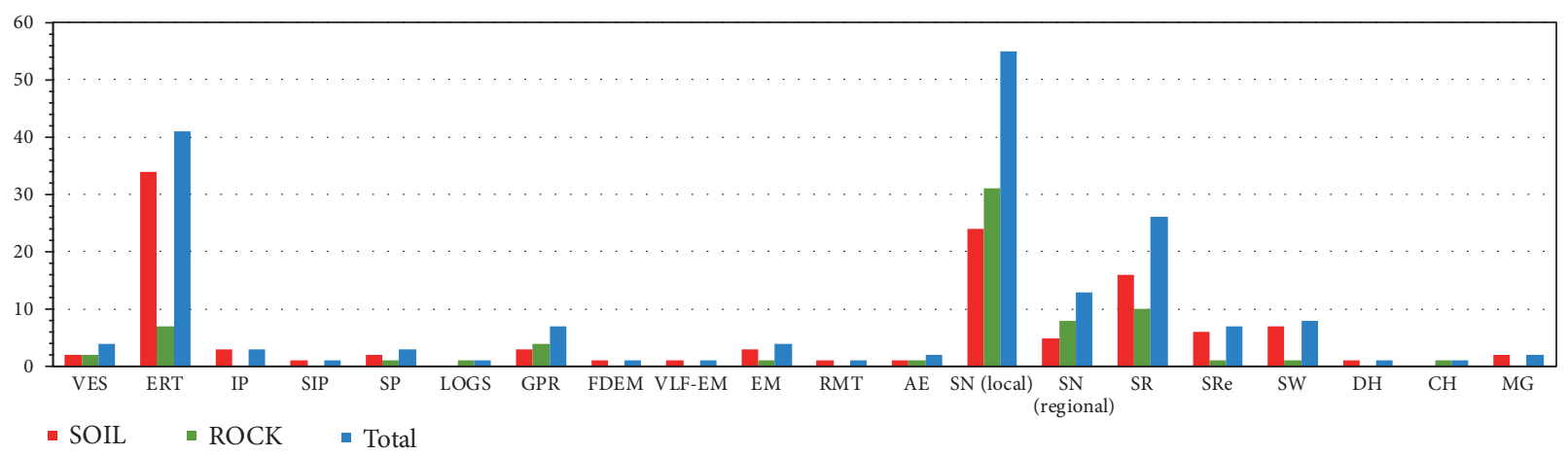

Figure 2: For each landslide typology ("soil" in red, "rock" in green, and total in blue), the bar graph shows the number of papers focused on each geophysical method.

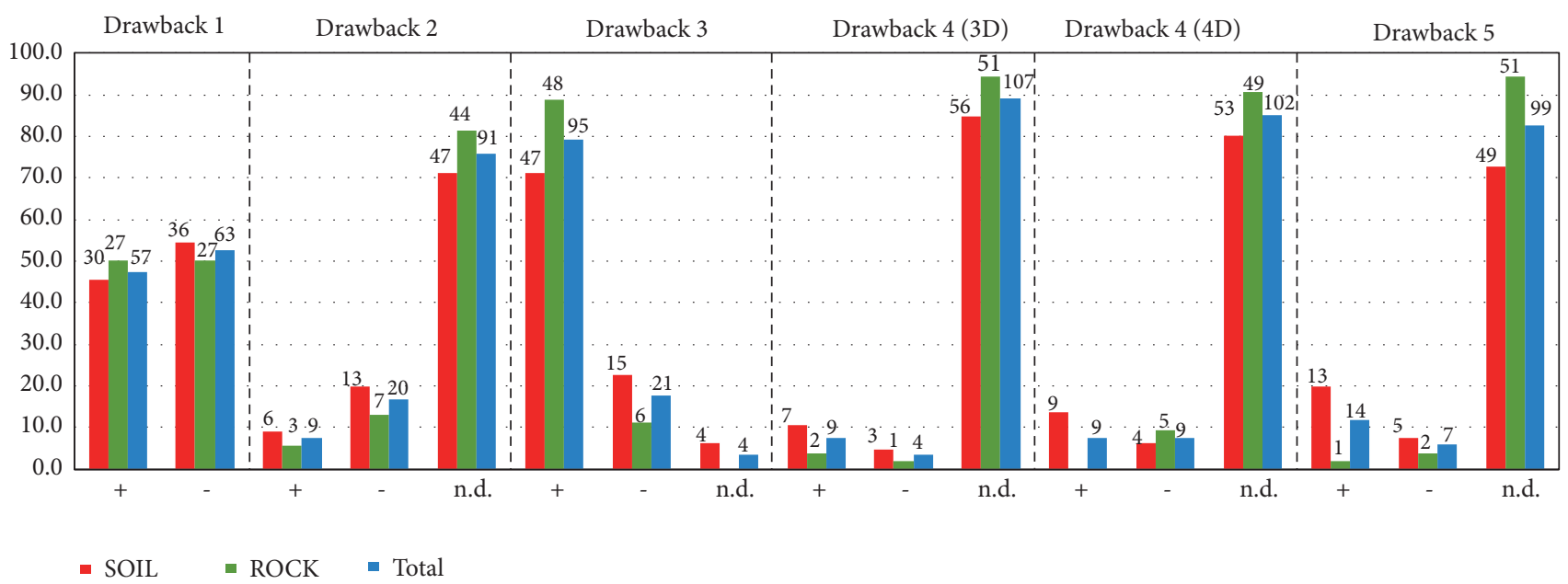

FIGURE 3: The bar graph indicates the percentage of efforts made (+ means many/some, - means insufficient, and n.d. means nondiscussed) to overcome each drawback. The percentages of papers focused on "soil" landslides are in red, those of papers focused on "rock" landslides are in green, while in blue are the total percentages. The numbers on the top of each bar indicate the numbers of papers.

4: 107 papers for 3D applications and 102 papers for 4D applications out of the 120 analysed, which are $89.2 \%$ and $85.0 \%$, respectively, are on the + level of the scale), and (c) to obtain quantitative information in terms of geotechnical parameters and hydrological properties from geophysical data (drawback 5: 99 papers out of the 120 analysed, which are $82.5 \%$, are on the n.d. level of the scale). Finally, thanks to the development of new 2D and 3D imaging software, some efforts, but still not enough (57 papers out of the 120 analysed, which is $47.5 \%$, are on the + level of the scale), were made to show the geophysical results more clearly (drawback 1).

In the following discussion, we analyse point-by-point the efforts made to overcome each drawback highlighted by [11].

Drawback 1: Geophysicists Have to Make an Effort in the Presentation of Their Results. According to our analysis (Figure 3), the efforts to overcome this drawback were performed more or less in the same way for both "soil" and "rock" landslides. This means that a tendency to show and present the results more objectively is beginning to emerge. This could be possible thanks to the development of new $2 \mathrm{D}$ and $3 \mathrm{D}$ software that allow the integration of data from different sources and surveys (e.g., geophysical, geotechnical, and borehole data). Nevertheless, the presentation of seismic data is sometimes still hard, since authors often show the rough traces or spectra (e.g., [22, 24, 26, 29, 39, 40, 44, 47, $49,55,56,58,64,76,84,89,95,97,98,101,103,104,106,112$, $116,117,121,126,127,131,133])$ that could be difficult to read for a nonexpert audience.

Drawback 2: The Spatial Resolution and Penetration Depth of Each Method Are Not Systematically Discussed in an Understandable Way. Each technique has a different resolution and penetration depth that contribute to the final quality of a geometrical model. According to [7], several preprocessing steps are needed to carefully check the data quality and, therefore, the resolution and penetration depth before incorporation into a $3 \mathrm{D}$ model. In total, $75.8 \%$ of the analysed papers ( 47 of those on "soil" landslides and 44 of those on the "rock" type) do not discuss either the resolution or the penetration depth of the presented methodology (Figure 3). Additionally, in the review in [20], none of the cited papers within the year range (2007-2013) examine these two points. In contrast, in the remaining $24.2 \%$ (Figure 3 ) of the examined works, 
these two points are discussed more in depth in nine papers $[7,23,27,38,62,68,93,105,128]$, and only few words are presented in the other twenty $[25,33,41,43,49,50,67,73-$ $75,78,80,85,87,90,92,108,110,132]$. Therefore, most of the authors who present the results of an integrated survey do not discuss how to consider and combine these data. It is possible to conclude that this drawback has still not been overcome since 2007 and the review in [11].

Drawback 3: The Geological Interpretation of Geophysical Data Should Be More Clearly and Critically Explained. The 3D internal structural characterization of a slope/cliff is essential to any landslide stability analysis and to hydro-mechanical modelling [7]. Nevertheless, interdisciplinary aspects between geomorphological and geophysical data/results are poorly addressed [19]. According to our review (Figure 3), in $79.2 \%$ of the analysed papers (47 of those on "soil" landslides and 48 of those on the "rock" type), many efforts have been made to interpret, show, and explain the geophysical data in a more clear and critical way. However, almost $50.0 \%$ of these works (those marked with $+*$ in Tables 2 and 3, which total 11 of 47 for "soil" landslides and 36 of 48 for the "rock" type) involve passive seismic monitoring and data analysis and interpretation to (a) provide information on slope dynamics and (b) identify landslide features. Moreover, it is worthwhile to note that the geophysical data interpretations are still not indisputable. In many papers, in fact, the discussion of the results is accompanied by words such as "suspect," "suppose," "speculate," "probably/probable," "potential," "our preferred interpretation," and "provide important information on possible" $[9,22,25-27,35,38-40,42-44,46,48-53,57,58,63,68$, $72,74,75,77,85,86,96,99,101,102,104,106,108-110$, $112,114,115,118,122,126,134]$. Without close collaboration between geophysicists and geomorphologists, the accurate and effective use of geophysical techniques, as well as the corresponding data interpretation, is often very limited [19].

Drawback 4: The Challenge for Geophysicists Is to Convince Geologists and Engineers That 3D and 4D Geophysical Imaging Techniques Can Be Valuable Tools for Investigating and Monitoring Landslides. In the hydrocarbon industry, the best strategy for reconstructing a high-resolution model is acquiring a $3 \mathrm{D}$ data set [31]. On the other hand, there are interesting results from the noninvasive time-lapse monitoring of the hydrological behaviour of a mountain slope [139]. However, in $89.2 \%$ of the analysed works (Figure 3) 3D geophysical imaging is not discussed. Even though the $3 \mathrm{D}$ volumetric reconstruction of a landslide is a suitable target with new technologies [46, 60, 65, 92], a 3D survey could be very tiring, exhausting, and time-consuming, since it is still difficult to carry and move the equipment over the slope [18, 20]. To overcome this limitation, the acquisition is usually performed by means of $2 \mathrm{D}$ parallel profiles, and the results are shown in a $3 \mathrm{D}$ fence diagram [[20] and references within, [27, 51, 52, $57,86,92,124]]$. Thus, this drawback highlighted by [11] has not been overcome and is still a challenge for geophysicists.

Passive seismic monitoring could be considered a $4 \mathrm{D}$ technique, but none of the authors refer to this method in this way. Therefore, in our analysis, we also have not considered it as a $4 \mathrm{D}$ technique, and the results show that in $85 \%$ of the works (Figure 3), 4D geophysical imaging is not discussed. In general, 4D ERT has been more frequently employed thanks to the development of ER multichannel measuring systems that significantly reduced the acquisition time [20, 140]. These systems [such as those employed in [141, 142]], in fact, (i) are able to simultaneously acquire a number of potential measurements for a single pair of current electrodes and (ii) can be set up to provide ERT at specific times during the day. Nevertheless, even though tl-ERTs could be helpfully employed in landslide monitoring, since they could provide information about the water content changes (i.e., the data could be related to pore water pressure variations and, therefore, to landslide triggering mechanisms), there are still few examples of 4D ERTs in landslide areas [60, 65, 92]. Moreover, it is still needed to improve software such that it is able to (i) continuously (or very frequently) process acquired data (e.g., ErtLab by Geostudy Astier, [140]), (ii) to link ER variations with hydrological parameter changes, and (ii) to take into account that the positions of the electrodes could change over the time because of the landslide movement $[38,65]$.

Drawback 5: Efforts Should Also Be Made towards Obtaining Quantitative Information from Geophysics in Terms of Geotechnical Parameters and Hydrological Properties. Authors agree that seismic wave velocities and soil ER could be useful in identifying anomalies related to structural (faults, fissures, and stability), lithological (sand to clay or calcareous variations) and hydrological (moisture, water flow) conditions [42, 123, 143]. However, drillings and inclinometer measurements are still crucial to providing a reliable idea of landslide structures and slip surfaces and to validate any geophysical measurements. This is probably because the geophysical property ranges cover several orders of magnitude, and a measured parameter cannot be directly assigned to a sure substrate. Currently, the major difficulty of applying geophysical techniques to landslides, as also highlighted by [11], is still the complex relationship between the measured geophysical parameters and the desired geotechnical and hydrogeological properties, which prevents the provision, in terms of engineering properties, of a straightforward interpretation. Moreover, a very accurate and high-resolution survey can still only be done on a small landslide portion $[23,24,27,28,38,40$, $46,60,78,86,92]$, as it is costly and time-consuming. As also pointed out by [143], this complexity in obtaining quantitative information from geophysical data is probably also caused by (a) the lack of knowledge about geophysics techniques in the geotechnical engineering/geological community and (b) engineers inclination to believe in soil and rock that they can see visually (borehole log), rather than in what they cannot see (geophysical signal).

These abovementioned limitations are confirmed by our analysis. In total, $82.5 \%$ of the works (99 of 120 , Figure 3 ), in fact, do not discuss how to obtain quantitative information on geotechnical and hydrogeological properties from geophysical data. In the remaining $17.5 \%$ (21 works, 14 of those on "soil" landslides and 7 of those on the "rock" type), both seismic 
and electrical methods are used in the same percentage ( 9 works focused on seismic methods, 8 on ER, and 4 on both seismic and ER methods). Thus, this drawback has still not been overcome, and laboratory surveys to establish a link between rock properties and geophysical data, as well as interdisciplinary communication and discussion, are the primary keys [90].

\section{Conclusion}

This review work analysed the papers published in openaccess journals from 2007 until today, focusing on the application of geophysical techniques to landslides. It was based on a "material landslide approach" analysis and evaluated how many efforts were performed to overcome the five drawbacks highlighted by the last review, which dates to 2007, concerning geophysical techniques applied to landslide monitoring and characterization. To quantify these efforts, a three-level scale was employed (from many/some efforts to nondiscussed). In general, it is possible to observe that (i) many efforts were made to improve the geological interpretation of geophysical data and to explain the interpretations more clearly and critically (drawback 3); (ii) some efforts, but still not enough, were made to show geophysical results more clearly (drawback 1); and (iii) very few efforts were made to (a) systematically discuss, in an understandable way, the resolution and penetration depth of each method (drawback 2), (b) to convince geologists and engineers that $3 \mathrm{D}$ and $4 \mathrm{D}$ geophysical imaging techniques can be valuable tools for investigating and monitoring landslides (drawback 4), and (c) to obtain quantitative information in terms of geotechnical parameters and hydrological properties from geophysical data (drawback 5).

The most studied landslides are those of the flow type for "soil" landslide typology and those of the fall type for the "rock" category. From the "employed method" point of view, active and passive seismic methods are the most employed in landslide characterization and monitoring. The latest method is also able to remotely detect events that might otherwise go unnoticed for weeks or months, and therefore, it is widely employed. The three more frequently applied techniques, regardless the typology ("soil" or "rock"), are ERT, SN and SR, which are to both characterize and monitor the slope deformation. Finally, independently of the applied technique/s, a very accurate and high-resolution survey could be performed only on a small landslide portion, as it is costly and time-consuming.

\section{Conflicts of Interest}

The authors declare that they have no conflicts of interest.

\section{References}

[1] T. J. Burke, D. N. Sattler, and T. Terich, "The socioeconomic effects of a landslide in western washington," Environmental Hazards, vol. 4, no. 4, pp. 129-136, 2002.
[2] D. M. Cruden and D. J. Varnes, "Landslide types and processes," Special Report - National Research Council, Transportation Research Board, vol. 247, pp. 36-75, 1996.

[3] D. J. Varnes, "Slope movement type and processes," in Landslides, Analysis and Control. Special Report 176, R. L. Schuster and R. J. Krizek, Eds., pp. 11-33, Transportation Research Board, National Academy Of Sciences, Wash, DC., USA, 1978.

[4] O. Hungr, S. Leroueil, and L. Picarelli, "The Varnes classification of landslide types, an update," Landslides, vol. 11, no. 2, pp. 167194, 2014.

[5] O. Hungr, S. G. Evans, M. J. Bovis, and J. N. Hutchinson, "A review of the classification of landslides of the flow type," Environmental and Engineering Geoscience, vol. 7, pp. 221-238, 2001.

[6] D. J. Varnes, "Landslide types and processes," in Landslides and Engineering Practice, Special Report 28, E. B. Eckel, Ed., pp. 2047, Highway research board. National Academy of Sciences, Wash, DC., USA, 1954.

[7] J. Travelletti and J. Malet, "Characterization of the 3D geometry of flow-like landslides: A methodology based on the integration of heterogeneous multi-source data," Engineering Geology, vol. 128, pp. 30-48, 2012.

[8] V. A. Bogoslovsky and A. A. Ogilvy, "Geophysical methods for the investigation of landslides," Geophysics, vol. 42, no. 3, pp. 562-571, 1977.

[9] J. Travelletti, J. Malet, K. Samyn, G. Grandjean, and M. Jaboyedoff, "Control of landslide retrogression by discontinuities: evidence by the integration of airborne-and ground-based geophysical information," Landslides, vol. 10, no. 1, pp. 37-54, 2013.

[10] V. Pazzi, L. Tanteri, G. Bicocchi, M. D’Ambrosio, A. Caselli, and R. Fanti, "H/V measurements as an effective tool for the reliable detection of landslide slip surfaces: Case studies of Castagnola (La Spezia, Italy) and Roccalbegna (Grosseto, Italy)," Physics and Chemistry of the Earth, Parts A/B/C, vol. 98, pp. 136-153, 2017.

[11] D. Jongmans and S. Garambois, "Geophysical investigation of landslides : a review," Bulletin de la Société Géographique de France, vol. 178, no. 2, pp. 101-112, 2007.

[12] R. Hack, "Geophysics for slope stability," Surveys in Geophysics, vol. 21, no. 4, pp. 423-448, 2000.

[13] R. Fell, O. Hungr, S. leroueil, and W. Riemer, "Keynote paper Geotechnical engineering of the stability of natural slopes and cuts and fills in soil," in Proceedings of The International Conference on Geotechnical \& Geological Engineering in Melbourne, Australia, vol. 1, pp. 21-120, Technomic Publishing, Lancaster, UK, 2000, ISBN: 1-58716-067-6.

[14] D. M. McCann and A. Foster, "Reconnaissance geophysical methods in landslide investigation," Engineering Geology, vol. 29, pp. 59-78, 1990.

[15] F. Bruno and F. Marillier, "Test of high-resolution seismic reflection and other geophysical techniques on the Boup landslide in the Swiss Alps," Surveys in Geophysics, vol. 21, no. 4, pp. 333-348, 2000.

[16] A. Perrone, A. Iannuzzi, V. Lapenna et al., "High-resolution electrical imaging of the Varco d'Izzo earthflow (southern Italy)," Journal of Applied Geophysics, vol. 56, no. 1, pp. 17-29, 2004.

[17] V. Naudet, M. Lazzari, A. Perrone, A. Loperte, S. Piscitelli, and V. Lapenna, "Integrated geophysical and geomorphological approach to investigate the snowmelt-triggered landslide of 
Bosco Piccolo village," Engineering Geology, vol. 98, no. 3-4, pp. 156-167, 2008.

[18] J. Chambers, P. Wilkinson, O. Kuras et al., “Three-dimensional geophysical anatomy of an active landslide in Lias Group mudrocks, Cleveland Basin, UK," Geomorphology, vol. 125, no. 4, pp. 472-484, 2011.

[19] L. Schrott and O. Sass, "Application of field geophysics in geomorphology: Advances and limitations exemplified by case studies," Geomorphology, vol. 93, no. 1-2, pp. 55-73, 2008.

[20] A. Perrone, V. Lapenna, and S. Piscitelli, "Electrical resistivity tomography technique for landslide investigation: a review," Earth-Science Reviews, vol. 135, pp. 65-82, 2014.

[21] A. Melehmir, L. V. Socco, M. Bastani et al., "Near-surface geophysical characterization of areas prone to natural hazards: a review of the current and perspective on the future," Advances in Geophysics, vol. 57, pp. 51-146, 2016.

[22] D. Amitrano, S. Gaffet, J. Malet, and O. Maquaire, "Understanding mudslides through micro-seismic monitoring: the supersauze (South French Alps) case study," Bulletin de la Société Géographique de France, vol. 178, no. 2, pp. 149-157, 2007.

[23] P. Bordoni, J. Haines, G. Di Giulio et al., "the cavola experiment team, 2007. cavola experiment site: geophysical investigation and deployment of a dense seismic array on s landslide," Annals of Geophysics, vol. 50, pp. 627-649, 2007.

[24] V. Del Gaudio and J. Wasowski, "Directivity of slope dynamic response to seismic shaking," Geophysical Research Letters, vol. 34, no. 12, 2007.

[25] G. Grandjean, J. Malet, A. Bitri, and O. Méric, "Geophysical data fusion by fuzzy logic for imaging the mechanical behaviour of mudslides," Bulletin de la Société Géographique de France, vol. 178, no. 2, pp. 127-136, 2007.

[26] C. Huang, H. Yin, C. Chen, C. Yeh, and C. Wang, "Ground vibrations produced by rock motions and debris flows," Journal of Geophysical Research: Atmospheres, vol. 112, Article ID F02014, 2007.

[27] O. Méric, S. Garambois, J.-P. Malet, H. Cadet, P. Guéguen, and D. Jongmans, "Seismic noise-based methods for soft-rock landslide characterization," Bulletin de la Société Géographique de France, vol. 178, no. 2, pp. 137-148, 2007.

[28] G. Danneels, C. Bourdeau, I. Torgoev, and H.-B. Havenith, "Geophysical investigation and dynamic modelling of unstable slopes: case-study of Kainama (Kyrgyzstan)," Geophysical Journal International, vol. 175, no. 1, pp. 17-34, 2008.

[29] V. Del Gaudio, S. Coccia, J. Wasowski, M. R. Gallipoli, and M. Mucciarelli, "Detection of directivity in seismic site response from microtremor spectral analysis," Natural Hazards and Earth System Sciences, vol. 8, no. 4, pp. 751-762, 2008.

[30] A. Burtin, L. Bollinger, R. Cattin, J. Vergne, and J. L. Nábělek, "Spatiotemporal sequence of Himalayan debris flow from analysis of high-frequency seismic noise," Journal of Geophysical Research: Atmospheres, vol. 114, no. F4, Article ID F04009, 2009.

[31] C. G. Eichkitz, M. G. Schreilechner, J. Amtmann, and C. Schmid, "Shallow seismic reflection study of the Gschliefgraben landslide deposition area - Interpretation and three dimensional modeling," Austrian Journal of Earth Sciences, vol. 102, no. 2, pp. 52-60, 2009.

[32] R. Marschallinger, C. Eichkitz, H. Gruber, K. Heibl, R. Hofmann, and K. Schmid, "The Gschliefgraben landslide (Austria): A remediation approach involving torrent and avalanche control, geology, geophysics, geotechnics and geoinformatics," Austrian Journal of Earth Sciences, vol. 102, no. 2, pp. 36-51, 2009.
[33] E. Stucchi and A. Mazzotti, "2D seismic exploration of the Ancona landslide (Adriatic Coast, Italy)," Geophysics, vol. 74, no. 5, pp. B139-B151, 2009.

[34] T. Lebourg, M. Hernandez, S. Zerathe, S. El Bedoui, H. Jomard, and B. Fresia, "Landslides triggered factors analysed by time lapse electrical survey and multidimensional statistical approach," Engineering Geology, vol. 114, no. 3-4, pp. 238-250, 2010.

[35] J.-S. L'Heureux, L. Hansen, O. Longva, A. Emdal, and L. O. Grande, "A multidisciplinary study of submarine landslides at the Nidelva fjord delta, Central Norway- Implications for geohazard assessment," Norsk Geologisk Tidsskrift, vol. 90, no. 1-2, pp. 1-20, 2010.

[36] F. Renalier, D. Jongmans, M. Campillo, and P. Bard, "Shear wave velocity imaging of the Avignonet landslide (France) using ambient noise cross correlation," Journal of Geophysical Research: Atmospheres, vol. 115, no. F3, Article ID F03032, 2010.

[37] S. P. Sharma, K. Anbarasu, S. Gupta, and A. Sengupta, "Integrated very low-frequency EM, electrical resistivity, and geological studies on the Lanta Khola landslide, North Sikkim, India," Landslides, vol. 7, no. 1, pp. 43-53, 2010.

[38] P. B. Wilkinson, J. E. Chambers, P. I. Meldrum, D. A. Gunn, R. D. Ogilvy, and O. Kuras, "Predicting the movements of permanently installed electrodes on an active landslide using timelapse geoelectrical resistivity data only," Geophysical Journal International, vol. 183, no. 2, pp. 543-556, 2010.

[39] V. Del Gaudio and J. Wasowski, "Advances and problems in understanding the seismic response of potentially unstable slopes," Engineering Geology, vol. 122, no. 1-2, pp. 73-83, 2011.

[40] J. Gomberg, W. Schulz, P. Bodin, and J. Kean, "Seismic and geodetic signatures of fault slip at the Slumgullion Landslide Natural Laboratory," Journal of Geophysical Research: Atmospheres, vol. 116, no. B9, Article ID B09404, 2011.

[41] J. Gance, G. Grandjean, K. Samyn, and J. Malet, "Quasi-Newton inversion of seismic first arrivals using source finite bandwidth assumption: application to subsurface characterization of landslides," Journal of Applied Geophysics, vol. 87, pp. 94-106, 2012.

[42] G. Grandjean, "A multi-method geophysical approach based on fuzzy logic for an integrated interpretation of landslides: application to the French Alps," Near Surface Geophysics, vol. 10, no. 6, pp. 601-611, 2012.

[43] C. Hibert, G. Grandjean, A. Bitri, J. Travelletti, and J. Malet, "Characterizing landslides through geophysical data fusion: Example of the La Valette landslide (France)," Engineering Geology, vol. 128, pp. 23-29, 2012.

[44] H. Kao, C. Kan, R. Chen et al., "Locating, monitoring, and characterizing typhoon- linduced landslides with real-time seismic signals. Landslides," Landslides, vol. 9, no. 4, pp. 557$563,2012$.

[45] R. Luongo, A. Perrone, S. Piscitelli, and V. Lapenna, "A prototype system for time-lapse electrical resistivity tomographies," International Journal of Geophysics, vol. 2012, Article ID 176895, 12 pages, 2012.

[46] K. Samyn, J. Travelletti, A. Bitri, G. Grandjean, and J. Malet, "Characterization of a landslide geometry using 3D seismic refraction traveltime tomography: The La Valette landslide case history," Journal of Applied Geophysics, vol. 86, pp. 120-132, 2012.

[47] M. Yamada, Y. Matsushi, M. Chigira, and J. Mori, "Seismic recordings of landslides caused by Typhoon Talas (2011), Japan," Geophysical Research Letters, vol. 39, no. 13, Article ID L13301, 2012. 
[48] T. Dahlin, H. Löfroth, D. Schälin, and P. Suer, "Mapping of quick clay using geoelectrical imaging and CPTU-resistivity," Near Surface Geophysics, vol. 11, no. 6, pp. 659-670, 2013.

[49] V. Del Gaudio, J. Wasowski, and S. Muscillo, "New developments in ambient noise analysis to characterise the seismic response of landslide-prone slopes," Natural Hazards and Earth System Sciences, vol. 13, no. 8, pp. 2075-2087, 2013.

[50] P. Lehmann, F. Gambazzi, B. Suski et al., "Evolution of soil wetting patterns preceding a hydrologically induced landslide inferred from electrical resistivity survey and point measurements of volumetric water content and pore water pressure," Water Resources Research, vol. 49, no. 12, pp. 7992-8004, 2013.

[51] A. Malehmir, M. Bastani, C. M. Krawczyk et al., "Geophysical assessment and geotechnical investigation of quick-clay landslides - a Swedish case study," Near Surface Geophysics, vol. 11, no. 3, pp. 341-352, 2013.

[52] A. Malehmir, M. U. Saleem, and M. Bastani, "High-resolution reflection seismic investigations of quick-clay and associated formations at a landslide scar in southwest Sweden," Journal of Applied Geophysics, vol. 92, pp. 84-102, 2013.

[53] R. G. Sastry and S. K. Mondal, "Geophysical characterization of the Salna Sinking zone, Garhwal Himalaya, India," Surveys in Geophysics, vol. 34, no. 1, pp. 89-119, 2013.

[54] S. Springman, A. Thielen, P. Kienzler, and S. Friedel, "A long-term field study for the investigation of rainfall-induced landslides," Géotechnique, vol. 63, no. 14, pp. 1177-1193, 2013.

[55] A. Tonnellier, A. Helmstetter, J. Malet, J. Schmittbuhl, A. Corsini, and M. Joswig, "Seismic monitoring of soft-rock landslides: the super-sauze and valoria case studies," Geophysical Journal International, vol. 193, no. 3, pp. 1515-1536, 2013.

[56] M. Yamada, H. Kumagai, Y. Matsushi, and T. Matsuzawa, "Dynamic landslide processes revealed by broadband seismic records," Geophysical Research Letters, vol. 40, no. 12, pp. 29983002, 2013.

[57] P. Capizzi and R. Martorana, "Integration of constrained electrical and seismic tomographies to study the landslide affecting the cathedral of Agrigento," Journal of Geophysics and Engineering, vol. 11, no. 4, Article ID 045009, 2014.

[58] V. Del Gaudio, S. Muscillo, and J. Wasowski, "What we can learn about slope response to earthquakes from ambient noise analysis: An overview," Engineering Geology, vol. 182, pp. 182200, 2014.

[59] C. Lissak, O. Maquaire, J. Malet et al., "Airborne and groundbased data sources for characterizing the morpho-structure of a coastal landslide," Geomorphology, vol. 217, pp. 140-151, 2014.

[60] A. J. Merritt, J. E. Chambers, W. Murphy et al., "3D ground model development for an active landslide in Lias mudrocks using geophysical, remote sensing and geotechnical methods," Landslides, vol. 11, no. 4, pp. 537-550, 2014.

[61] E. Stucchi, A. Ribolini, and A. Anfuso, "High-resolution reflection seismic survey at the Patigno landslide, Northern Apennines, Italy," Near Surface Geophysics, vol. 12, no. 4, pp. 559-571, 2013.

[62] R. Supper, D. Ottowitz, B. Jochum et al., "Geoelectrical monitoring: an innovative method to supplement landslide surveillance and early warning," Near Surface Geophysics, vol. 12, no. 1, pp. 133-150, 2013.

[63] R. Iverson, D. George, K. Allstadt et al., "Landslide mobility and hazards: implications of the 2014 Oso disaster," Earth and Planetary Science Letters, vol. 412, pp. 197-208, 2015.
[64] M. Ogiso and K. Yomogida, "Estimation of locations and migration of debris flows on Izu-Oshima Island, Japan, on 16 October 2013 by the distribution of high frequency seismic amplitudes," Journal of Volcanology and Geothermal Research, vol. 298, pp. 15-26, 2015.

[65] S. Uhlemann, P. B. Wilkinson, J. E. Chambers et al., "Interpolation of landslide movements to improve the accuracy of $4 \mathrm{D}$ geoelectrical monitoring," Journal of Applied Geophysics, vol. 121, pp. 93-105, 2015.

[66] S. Yilmaz and C. Narman, "2-D electrical resistivity imaging for investigating an active landslide along a ridgeway in Burdur region, southern Turkey," Arabian Journal of Geosciences, vol. 8, no. 5, pp. 3343-3349, 2015.

[67] M. Fressard, O. Maquaire, Y. Thiery, R. Davidson, and C. Lissak, "Multi-method characterisation of an active landslide: Case study in the Pays d'Auge plateau (Normandy, France)," Geomorphology, vol. 270, pp. 22-39, 2016.

[68] J. Gance, J. Malet, R. Supper, P. Sailhac, D. Ottowitz, and B. Jochum, "Permanent electrical resistivity measurements for monitoring water circulation in clayey landslides," Journal of Applied Geophysics, vol. 126, pp. 98-115, 2016.

[69] Z. Hu and W. Shan, "Landslide investigations in the northwest section of the lesser Khingan range in China using combined HDR and GPR methods," Bulletin of Engineering Geology and the Environment, vol. 75, no. 2, pp. 591-603, 2016.

[70] D. Kušnirák, I. Dostál, R. Putiška, and A. Mojzeš, "Complex geophysical investigation of the Kapušany landslide (Eastern Slovakia)," Contributions to Geophysics and Geodesy, vol. 46, no. 2, pp. 111-124, 2016.

[71] C. Ling, Q. Xu, Q. Zhang, J. Ran, and H. Lv, "Application of electrical resistivity tomography for investigating the internal structure of a translational landslide and characterizing its groundwater circulation (Kualiangzi landslide, Southwest China)," Journal of Applied Geophysics, vol. 131, pp. 154-162, 2016.

[72] I. Solberg, M. Long, V. C. Baranwal, A. S. Gylland, and J. S. Rønning, "Geophysical and geotechnical studies of geology and sediment properties at a quick-clay landslide site at Esp, Trondheim, Norway," Engineering Geology, vol. 208, pp. 214230, 2016.

[73] S. Szalai, K. Szokoli, M. Metwaly, Z. Gribovszki, and E. Prácser, "Prediction of the location of future rupture surfaces of a slowly moving loess landslide by electrical resistivity tomography," Geophysical Prospecting, vol. 65, no. 2, pp. 596-616, 2017.

[74] S. Uhlemann, S. Hagedorn, B. Dashwood et al., "Landslide characterization using P- and S-wave seismic refraction tomography - The importance of elastic moduli," Journal of Applied Geophysics, vol. 134, pp. 64-76, 2016.

[75] E. Yalcinkaya, H. Alp, and O. Ozel, "Near-surface geophysical methods for investigating the Buyukcekmece landslide in Istanbul, Turkey," Journal of Applied Geophysics, vol. 134, pp. 23-35, 2016.

[76] F. Walter, A. Burtin, B. W. McArdell, N. Hovius, B. Weder, and J. M. Turowski, "Testing seismic amplitude source location for fast debris-flow detection at Illgraben, Switzerland," Natural Hazards and Earth System Sciences, vol. 17, no. 6, pp. 939-955, 2017.

[77] H. Havenith, I. Torgoev, and A. Ischuk, "Integrated geophysicalgeological 3D model ofthe right-bank slope downstream from the rogun dam construction site, Tajikistan," International Journal of Geophysics, vol. 2018, Article ID 1641789, 16 pages, 2018. 
[78] A. Flores Orozco, M. Bücker, M. Steiner, and J. Malet, "Complex-conductivity imaging for the understanding of landslide architecture," Engineering Geology, vol. 243, pp. 241-252, 2018.

[79] G. Pappalardo, S. Imposa, M. S. Barbano, S. Grassi, and S. Mineo, "Study of landslides at the archaeological site of Abakainon necropolis (NE Sicily) by geomorphological and geophysical investigations," Landslides , vol. 15, no. 7, pp. 12791297, 2018.

[80] S. Rezaei, I. Shooshpasha, and H. Rezaei, "Reconstruction of landslide model from ERT, geotechnical, and field data, Nargeschal landslide, Iran," Bulletin of Engineering Geology and the Environment, vol. 78, no. 5, pp. 3223-3237, 2019.

[81] A. Schimmel, J. Hübl, B. McArdell, and F. Walter, "Automatic Identification of Alpine Mass Movements by a Combination of Seismic and Infrasound Sensors," Sensors, vol. 18, no. 5, p. 1658, 2018.

[82] K. Szokoli, L. Szarka, M. Metwaly, J. Kalmár, E. Prácser, and S. Szalai, "Characterisation of a landslide by its fracture system using electric resistivity tomography and pressure probe methods," Acta Geodaetica et Geophysica, vol. 53, no. 1, pp. 1530, 2018.

[83] N. Vouillamoz, S. Rothmund, and M. Joswig, "Characterizing the complexity of microseismic signals at slow-moving clay-rich debris slides: the Super-Sauze (southeastern France) and Pechgraben (Upper Austria) case studies," Earth Surface Dynamics, vol. 6 , no. 2, pp. 525-550, 2018.

[84] B. Bessason, G. Eiríksson, Ó. Thorarinsson, A. Thórarinsson, and S. Einarsson, "Automatic detection of avalanches and debris flows by seismic methods," Journal of Glaciology, vol. 53, no. 182, pp. 461-472, 2007.

[85] J. Deparis, S. Garambois, and D. Hantz, "On the potential of ground penetrating radar to help rock fall hazard assessment: a case study of a limestone slab, Gorges de la Bourne (French Alps)," Engineering Geology, vol. 94, no. 1-2, pp. 89-102, 2007.

[86] T. Spillmann, H. Maurer, A. G. Green, B. Heincke, H. Willenberg, and S. Husen, "Microseismic investigation of an unstable mountain slope in the Swiss Alps," Journal of Geophysical Research: Atmospheres, vol. 112, no. B7, Article ID B07301, 2007.

[87] J. Deparis, B. Fricout, D. Jongmans, T. Villemin, L. Effendiantz, and A. Mathy, "Combined use of geophysical methods and remote techniques for characterizing the fracture network of a potentially unstable cliff site (the 'Roche du Midi', Vercors massif, France)," Journal of Geophysics and Engineering, vol. 5, no. 2, pp. 147-157, 2008.

[88] J. Deparis, D. Jongmans, F. Cotton, L. Baillet, F. Thouvenot, and D. Hantz, "Analysis of rock-fall and rock-fall avalanche seismograms in the French alps," Bulletin of the Seismological Society of America, vol. 98, no. 4, pp. 1781-1796, 2008.

[89] S. C. Moran, R. S. Matoza, M. A. Garcés et al., "Seismic and acoustic recordings of an unusually large rockfall at Mount St. Helens, Washington," Geophysical Research Letters, vol. 35, no. 19, Article ID L19302, 2008.

[90] R. Supper, A. Römer, B. Jochum, G. Bieber, and W. Jaritz, "A complex geo-scientific strategy for landslide hazard mitigation - from airborne mapping to ground monitoring," Advances in Geosciences, vol. 14, pp. 195-200, 2008.

[91] I. Vilajosana, E. Suriñach, A. Abellán, G. Khazaradze, D. Garcia, and J. Llosa, "Rockfall induced seismic signals: case study in Montserrat, Catalonia," Natural Hazards and Earth System Sciences, vol. 8, no. 4, pp. 805-812, 2008.
[92] H. Willenberg, S. Loew, E. Eberhardt et al., "Internal structure and deformation of an unstable crystalline rock mass above Randa (Switzerland): Part I - Internal structure from integrated geological and geophysical investigations," Engineering Geology, vol. 101, no. 1-2, pp. 1-14, 2008.

[93] D. Arosio, L. Longoni, M. Papini, M. Scaioni, L. Zanzi, and M. Alba, "Towards rockfall forecasting through observing deformations and listening to microseismic emissions," Natural Hazards and Earth System Sciences, vol. 9, no. 4, pp. 1119-1131, 2009.

[94] G. Senfaute, A. Duperret, and J. A. Lawrence, "Micro-seismic precursory cracks prior to rock-fall on coastal chalk cliffs: a case study at Mesnil-Val, Normandie, NW France," Natural Hazards and Earth System Sciences, vol. 9, no. 5, pp. 1625-1641, 2009.

[95] D. Amitrano, M. Arattano, M. Chiarle et al., "Microseismic activity analysis for the study of the rupture mechanisms in unstable rock masses," Natural Hazards and Earth System Sciences, vol. 10, no. 4, pp. 831-841, 2010.

[96] J. Burjánek, G. Gassner-Stamm, V. Poggi, J. R. Moore, and D. Fäh, "Ambient vibration analysis of an unstable mountain slope," Geophysical Journal International, vol. 180, no. 2, pp. 820 828, 2010.

[97] S. Gaffet, Y. Guglielmi, F. Cappa, C. Pambrun, T. Monfret, and D. Amitrano, "Use of the simultaneous seismic, GPS and meteorological monitoring for the characterization of a large unstable mountain slope in the southern French Alps," Geophysical Journal International, vol. 182, no. 3, pp. 1395-1410, 2010.

[98] J. Got, P. Mourot, and J. Grangeon, "Pre-failure behaviour of an unstable limestone cliff from displacement and seismic data," Natural Hazards and Earth System Sciences, vol. 10, no. 4, pp. 819-829, 2010.

[99] A. Helmstetter and S. Garambois, "Seismic monitoring of Séchilienne rockslide (French Alps): Analysis of seismic signals and their correlation with rainfalls," Journal of Geophysical Research: Atmospheres, vol. 115, no. F3, Article ID F03016, 2010.

[100] C. Lévy, L. Baillet, D. Jongmans, P. Mourot, and D. Hantz, "Dynamic response of the Chamousset rock column (Western Alps, France)," Journal of Geophysical Research: Atmospheres, vol. 115, no. F4, Article ID F04043, 2010.

[101] D. Schneider, P. Bartelt, J. Caplan-Auerbach, M. Christen, C. Huggel, and B. W. McArdell, "Insights into rock-ice avalanche dynamics by combined analysis of seismic recordings and a numerical avalanche model," Journal of Geophysical Research: Atmospheres, vol. 115, no. F4, Article ID F04026, 2010.

[102] J. Travelletti, J. Demand, M. Jaboyedoff, and F. Marillier, "Mass movement characterization using a reflexion and refraction seismic survey with the sloping local base level concept," Geomorphology, vol. 116, no. 1-2, pp. 1-10, 2010.

[103] F. Dammeier, J. R. Moore, F. Haslinger, and S. Loew, "Characterization of alpine rockslides using statistical analysis of seismic signals," Journal of Geophysical Research: Atmospheres, vol. 116, no. F4, Article ID F04024, 2011.

[104] C. Hibert, A. Mangeney, G. Grandjean, and N. M. Shapiro, "Slope instabilities in Dolomieu crater, Réunion Island: From seismic signals to rockfall characteristics," Journal of Geophysical Research: Atmospheres, vol. 116, no. F4, Article ID F04032, 2011.

[105] P. Lacroix and A. Helmstetter, "Location of seismic signals associated with microearthquakes and rockfalls on the sechilienne Landslide, French Alps," Bulletin of the Seismological Society of America, vol. 101, no. 1, pp. 341-353, 2011. 
[106] C. Levy, D. Jongmans, and L. Baillet, "Analysis of seismic signals recorded on a prone-to-fall rock column (Vercors massif, French Alps)," Geophysical Journal International, vol. 186, no. 1, pp. 296-310, 2011.

[107] J. R. Moore, V. Gischig, J. Burjánek, S. Loew, and D. Fäh, “Site effects in unstable rock slopes: dynamic behaviorof the randa instability (Switzerland)," Bulletin of the Seismological Society of America, vol. 101, no. 6, pp. 3110-3116, 2011.

[108] T. Pánek, K. Šilhán, P. Tábořík et al., "Catastrophic slope failure and its origins: Case of the May 2010 Girová Mountain longrunout rockslide (Czech Republic)," Geomorphology, vol. 130, no. 3-4, pp. 352-364, 2011.

[109] T. Pánek, P. Tábořík, J. Klimeš, V. Komárková, J. Hradecký, and M. Št'astný, "Deep-seated gravitational slope deformations in the highest parts of the Czech Flysch Carpathians: Evolutionary model based on kinematic analysis, electrical imaging and trenching," Geomorphology, vol. 129, no. 1-2, pp. 92-112, 2011.

[110] D. Amitrano, S. Gruber, and L. Girard, "Evidence of frostcracking inferred from acoustic emissions in a high-alpine rockwall," Earth and Planetary Science Letters, vol. 341-344, pp. 8693, 2012.

[111] J. Burjánek, J. R. Moore, F. X. Yugsi Molina, and D. Fäh, "Instrumental evidence of normal mode rock slope vibration," Geophysical Journal International, vol. 188, no. 2, pp. 559-569, 2012.

[112] C. Occhiena, V. Coviello, M. Arattano et al., "Analysis of microseismic signals and temperature recordings for rock slope stability investigations in high mountain areas," Natural Hazards and Earth System Sciences, vol. 12, no. 7, pp. 2283-2298, 2012.

[113] F. Panzera, S. D\&amp;apos;Amico, A. Lotteri, P. Galea, and G. Lombardo, "Seismic site response of unstable steep slope using noise measurements: the case study of Xemxija Bay area, Malta," Natural Hazards and Earth System Sciences, vol. 12, no. 11, pp. 3421-3431, 2012.

[114] M. Walter, C. Arnhardt, and M. Joswig, "Seismic monitoring of rockfalls, slide quakes, and fissure development at the SuperSauze mudslide, French Alps," Engineering Geology, vol. 128, pp. 12-22, 2012.

[115] M. Walter, U. Schwaderer, and M. Joswig, "Seismic monitoring of precursory fracture signals from a destructive rockfall in the Vorarlberg Alps, Austria," Natural Hazards and Earth System Sciences, vol. 12, no. 11, pp. 3545-3555, 2012.

[116] K. Allstadt, "Extracting source characteristics and dynamics of the August 2010 Mount Meager landslide from broadband seismograms," Journal of Geophysical Research: Earth Surface, vol. 118, no. 3, pp. 1472-1490, 2013.

[117] P. Bottelin, D. Jongmans, L. Baillet et al., "Spectral analysis of prone-to-fall rock compartments using ambient vibrations," Journal of Environmental \& Engineering Geophysics, vol. 18, no. 4, pp. 205-217, 2013.

[118] A. Burtin, N. Hovius, D. T. Milodowski et al., "Continuous catchment-scale monitoring of geomorphic processes with a 2D seismological array," Journal of Geophysical Research: Earth Surface, vol. 118, no. 3, pp. 1956-1974, 2013.

[119] R. P. Singh, C. S. Dubey, S. K. Singh et al., "A new slope mass rating in mountainous terrain, Jammu and Kashmir Himalayas: applicationof geophysical technique in slope stability studies," Landslides, vol. 10, no. 3, pp. 255-265, 2013.

[120] P. Bottelin, D. Jongmans, D. Daudon et al., "Seismic and mechanical studies of the artificially triggered rockfall at Mount
Néron (French Alps, December 2011)," Natural Hazards and Earth System Sciences, vol. 14, no. 12, pp. 3175-3193, 2014.

[121] C. Hibert, A. Mangeney, G. Grandjean et al., "Automated identification, location, and volume estimation of rockfalls at Piton de la Fournaise volcano," Journal of Geophysical Research: Earth Surface, vol. 119, no. 5, pp. 1082-1105, 2014.

[122] T. Pánek, F. Hartvich, V. Jankovská et al., "Large Late Pleistocene landslides from the marginal slope of the Flysch Carpathians," Landslides, vol. 11, no. 6, pp. 981-992, 2014.

[123] A. E. Akpan, A. O. Ilori, and N. U. Essien, "Geophysical investigation of Obot Ekpo Landslide site, Cross River State, Nigeria," Journal of African Earth Sciences, vol. 109, pp. 154-167, 2015.

[124] A. Viero, A. Galgaro, G. Morelli, A. Breda, and R. G. Francese, "Investigations on the structural setting of a landslide-prone slope by means of three-dimensional electrical resistivity tomography," Natural Hazards, vol. 78, no. 2, pp. 1369-1385, 2015.

[125] C. Colombero, C. Comina, G. Umili, and S. Vinciguerra, "Multiscale geophysical characterization of an unstable rock mass," Tectonophysics, vol. 675, pp. 275-289, 2016.

[126] F. Dammeier, J. R. Moore, C. Hammer, F. Haslinger, and S. Loew, "Automatic detection of alpine rockslides in continuous seismic data using hidden Markov models," Journal of Geophysical Research: Earth Surface, vol. 121, no. 2, pp. 351-371, 2016.

[127] A. Manconi, M. Picozzi, V. Coviello, F. De Santis, and L. Elia, "Real-time detection, location, and characterizationof rockslides using broadband regionalseismic networks," Geophysical Research Letters, vol. 43, no. 13, pp. 6960-6967, 2016.

[128] M. Dietze, S. Mohadjer, J. M. Turowski, T. A. Ehlers, and N. Hovius, "Seismic monitoring of small alpine rockfalls - validity, precision and limitation," Earth Surface Dynamics, vol. 5, no. 4, pp. 653-668, 2017.

[129] T. Gracchi, A. Lotti, G. Saccorotti et al., "A method for locating rockfall impacts using signals recorded by a microseismic network," Geoenvironmental Disasters, vol. 4, no. 1, article no 26, 2017.

[130] S. Imposa, S. Grassi, F. Fazio, G. Rannisi, and P. Cino, "Geophysical survey to study a landslide body (north-eastern Sicily)," Natural Hazards, vol. 86, pp. 327-343, 2017.

[131] F. Provost, C. Hibert, and J. Malet, "Automatic classification of endogenous landslide seismicity using the random forest supervised classifier," Geophysical Research Letters, vol. 44, no. 1, pp. 113-120, 2017.

[132] P. Tábořík, J. Lenart, V. Blecha, J. Vilhelm, and O. Turský, "Geophysical anatomy of counter-slope scarps in sedimentary flysch rocks (Outer Western Carpathians)," Geomorphology, vol. 276, pp. 59-70, 2017.

[133] D. Arosio, L. Longoni, M. Papini, M. Boccolari, and L. Zanzi, "Analysis of microseismic signals collected on an unstable rock face in the Italian Prealps," Geophysical Journal International, vol. 213, no. 1, pp. 475-488, 2018.

[134] J. Burjánek, V. Gischig, J. R. Moore, and D. Fäh, "Ambient vibration characterization and monitoring of a rock slope close to collapse," Geophysical Journal International, vol. 212, no. 1, pp. 297-310, 2018.

[135] A. Lotti, V. Pazzi, G. Saccorotti, A. Fiaschi, L. Matassoni, and G. Gigli, "HVSR analysis of rockslide seismic signals to assess the subsoil conditions and the site seismic response," International Journal of Geophysics, vol. 2018, Article ID 9383189, 11 pages, 2018. 
[136] M. Del Soldato, V. Pazzi, S. Segoni, P. De Vita, V. Tofani, and S. Moretti, "Spatial modelling of pyroclastic cover deposit thickness (depth to bedrock) in peri-volcanic areas of Campania (southern Italy)," Earth Surface Processes and Landforms, vol. 43, no. 9, pp. 1757-1767, 2018.

[137] L. V. Socco, D. Jongmans, D. Boiero et al., "Geophysical investigation of the Sandalp rock avalanche deposits," Journal of Applied Geophysics, vol. 70, no. 4, pp. 277-291, 2010.

[138] A. Lotti, G. Saccorotti, A. Fiaschi et al., "Seismic monitoring of rockslide: the Torgiovannetto quarry (Central Apennines, Italy)," in Engineering Geology for Society and Territory, G. Lollino, Ed., vol. 2, pp. 1537-1540, Springer International Publishing, Switzerland, 2014.

[139] G. Cassiani, A. Godio, S. Stocco et al., "Monitoring the hydrologic behaviour of a mountain slope via time-lapse electrical resistivity tomography," Near Surface Geophysics, vol. 7, no. 5-6, pp. 475-486, 2009.

[140] F. Fischanger, G. Morelli, G. Ranieri, G. Santarato, and M. Occhi, "4D cross-borehole electrical resistivity tomography to control resin injection for ground stabilization: a case history in Venice (Italy)," Near Surface Geophysics, vol. 11, no. 1, pp. 41-50, 2013.

[141] V. Pazzi, M. Ceccatelli, T. Gracchi, E. B. Masi, and R. Fanti, "Assessing subsoil void hazards along a road system using $\mathrm{H} / \mathrm{V}$ measurements, ERTs, and IPTs to support local decision makers," Near Surface Geophysics, vol. 16, no. 3, pp. 282-297, 2018.

[142] V. Pazzi, M. Di Filippo, M. Di Nezza et al., "Integrated geophysical survey in a sinkhole-prone area: Microgravity, electrical resistivity tomographies, and seismic noise measurements to delimit its extension," Engineering Geology, vol. 243, pp. 282293, 2018.

[143] W. Wai-Lok Lai, X. Dérobert, and P. Annan, "A review of Ground Penetrating Radar application in civil engineering: A 30 -year journey from Locating and Testing to Imaging and Diagnosis," NTD and E International, vol. 96, pp. 58-78, 2018. 

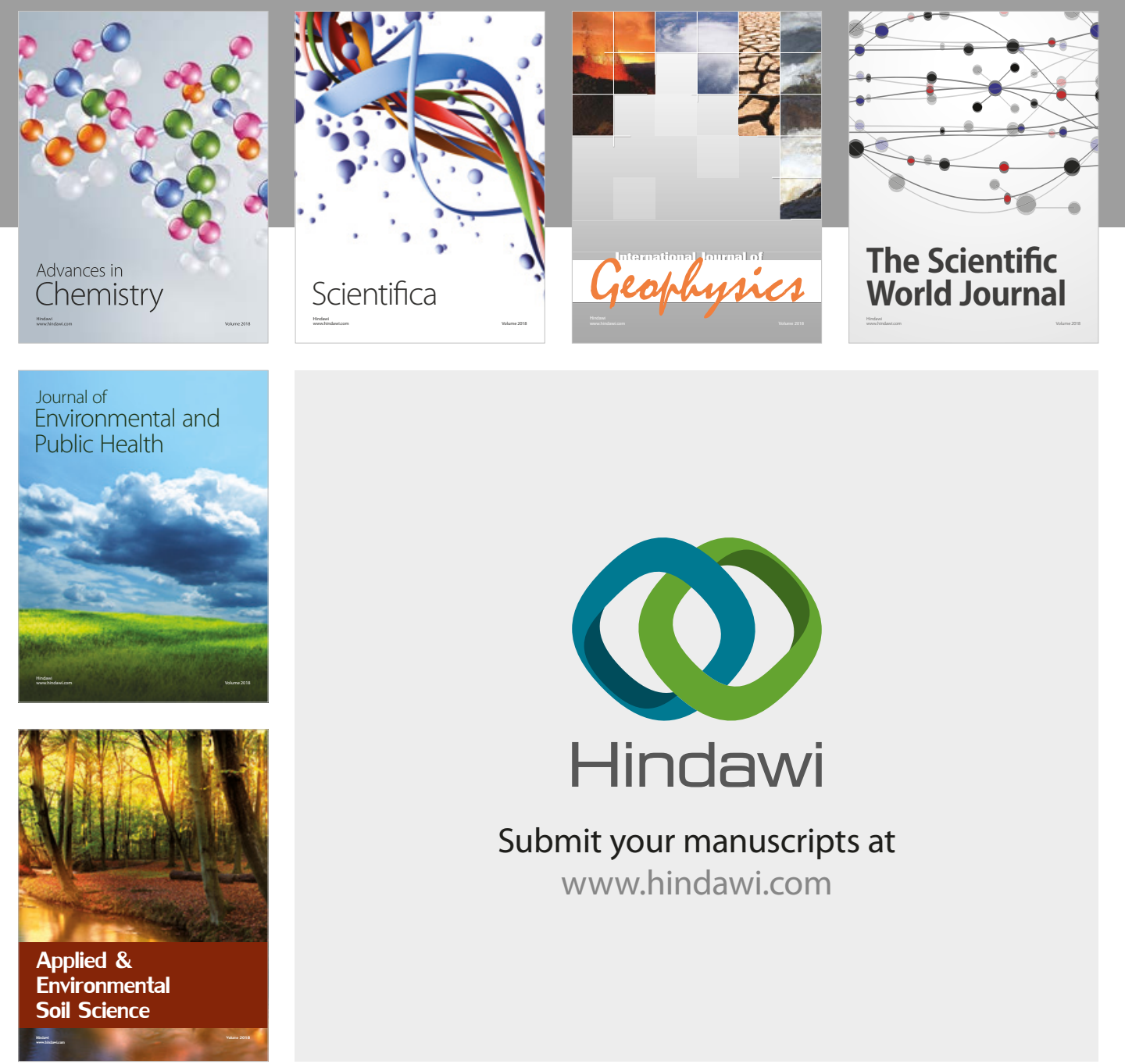

The Scientific

\section{World Journal}
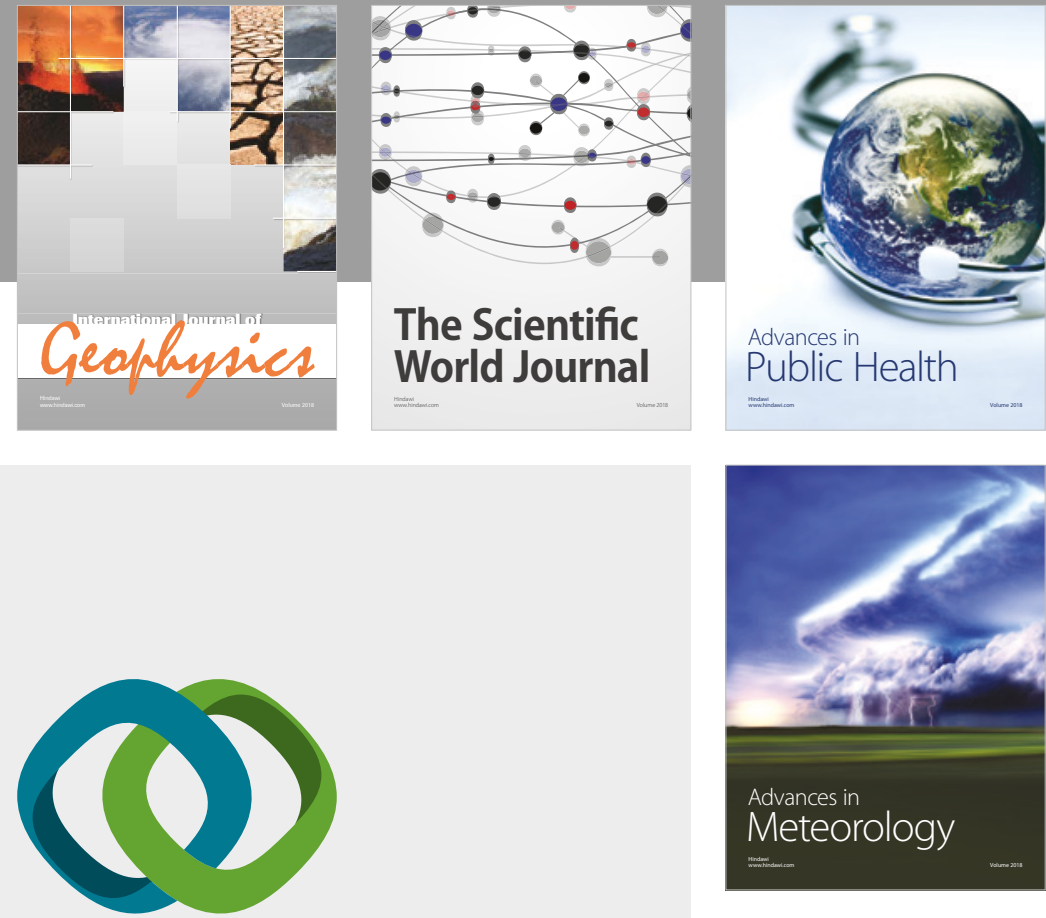

Advan

Public Health

\section{Hindawi}

Submit your manuscripts at

www.hindawi.com
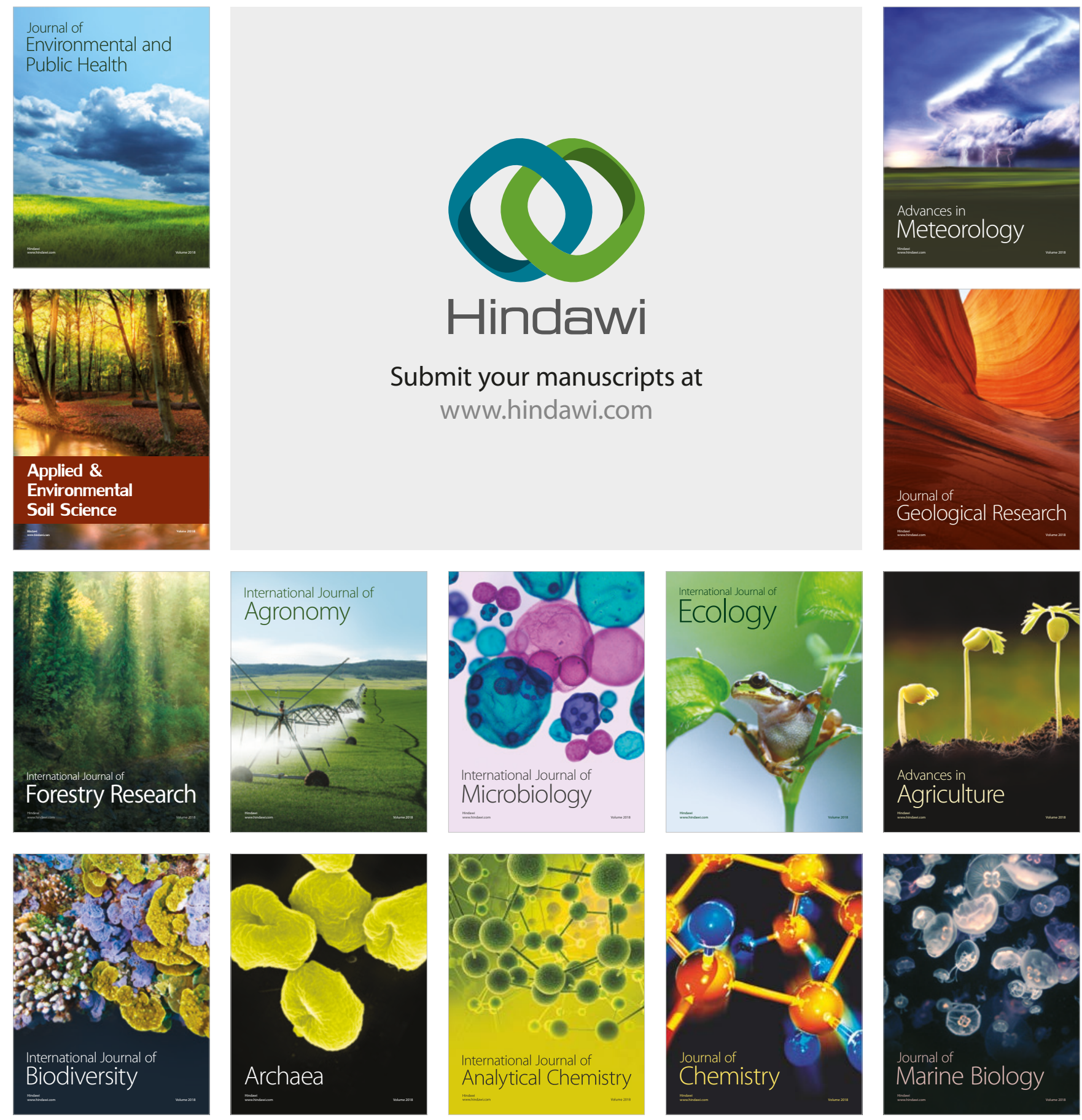